Prepared for the Southeast Regional Partnership for Planning and Sustainability (SERPPAS)

\title{
Historic and Forecasted Population and Land-Cover Change in Southeastern North Carolina, 1992-2030
}

By Peter R. Claggett, Paul P. Hearn, Jr., and David I. Donato

Open-File Report 2014-1125

U.S. Department of the Interior

U.S. Geological Survey 


\section{U.S. Department of the Interior \\ SALLY JEWELL, Secretary}

\section{U.S. Geological Survey \\ Suzette M. Kimball, Acting Director}

U.S. Geological Survey, Reston, Virginia: 2015

For more information on the USGS—-the Federal source for science about the Earth,

its natural and living resources, natural hazards, and the environment-visit

http://www.usgs.gov or call 1-888-ASK-USGS.

For an overview of USGS information products, including maps, imagery, and publications, visit http://www.usgs.gov/pubprod.

Any use of trade, firm, or product names is for descriptive purposes only and does not imply endorsement by the U.S. Government.

Although this information product, for the most part, is in the public domain, it also may contain copyrighted materials as noted in the text. Permission to reproduce copyrighted items must be secured from the copyright owner.

\section{Suggested citation:}

Claggett, P.R., Hearn, P.P., Jr., and Donato, D.I., 2015, Historic and forecasted population and land-cover change in southeastern North Carolina, 1992-2030: U.S. Geological Survey Open-File Report 2014-1125, 23 p., http://dx.doi.org/10.3133/ofr20141125.

ISSN 2331-1258 (online) 


\section{Contents}

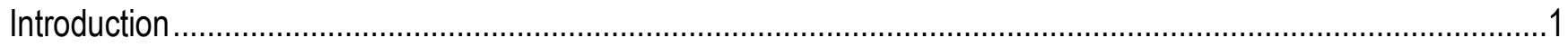

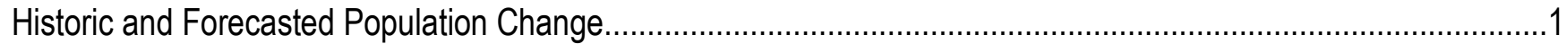

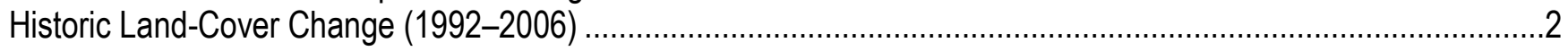

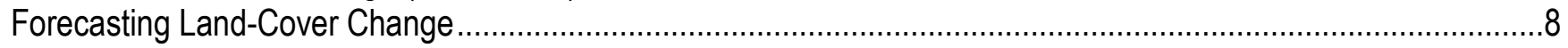

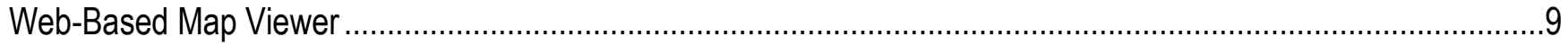

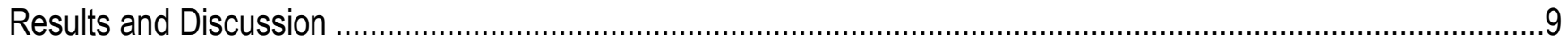

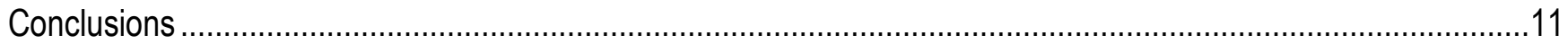

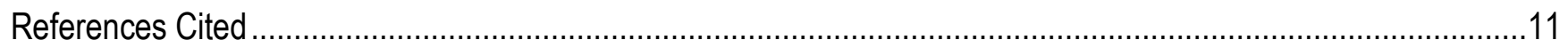

\section{Figures}

1. Map showing the 13-county study area in southeastern North Carolina................................................13

2. Graph showing historic and projected population growth in the 13-county study area, southeastern North Carolina ....................................................................................................................13

3. Map showing projected population change for the period 2010-30 in the 13-county study area,

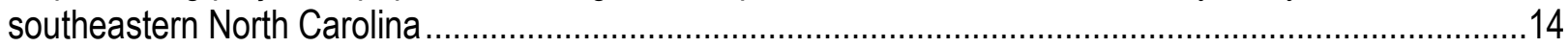

4. Map showing land-cover for a portion of North Carolina, 1992 ….....................................................14

5. Map showing areas of land-cover change for a portion of North Carolina, 1992-2006 ............................15

6. Map showing detail from figure 5 of land-cover change in Onslow and surrounding counties, North Carolina, 1992-2006......................................................................................................

7. Graph showing changes over time of the relative proportions of the nine aggregated land-cover types in the southeastern North Carolina study area ..........................................................................16

8. Map showing relative suitability for urban growth in southeastern North Carolina ....................................16

9. Map showing relative suitability for urban growth in Onslow County, North Carolina, and surrounding areas to the west ..............................................................................................................................

10. Map showing probability of urban growth in southeastern North Carolina by the year 2030.....................18

11. Map showing probabilities of urban growth in Onslow County, North Carolina, and surrounding areas

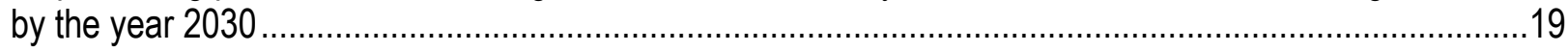

12. Web-based map viewer image showing growth suitability layer ........................................................19

13. Web-based map viewer image showing detail of urban growth forecasts for Wilmington, North Carolina, and surrounding areas.........................................................................................20

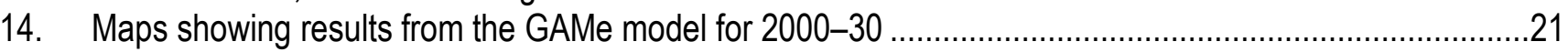

15. Maps showing results from the SLEUTH model .........................................................................22

16. Maps showing results from the combination of the GAMe and SLEUTH models ...................................23

\section{Tables}

1. Land-cover classes for southeastern North Carolina created by aggregating relevant classes defined for the National Oceanic and Atmospheric Administration's Coastal Change Analysis Program.................. 3

2. Land-cover change sub-tables for southeastern North Carolina: 1992-96, 1996-2001, and 2001-6.........4

3. Total amount of land in the study area that changed from one land-cover class to another during each of three time periods.

4. Summary of absolute and percentage net change in land cover by land-cover class in southeastern North Carolina during 1992-2006. 
5. Change in acreage by land-cover class for each of three time periods in the southeastern North Carolina study area.

6. Acres and percent of the total land area of the study area in southeastern North Carolina at four points in time. 


\section{Conversion Factors and Abbreviations}

\begin{tabular}{|c|c|c|}
\hline Multiply & By & To obtain \\
\hline \multicolumn{3}{|c|}{ Length } \\
\hline meter $(\mathrm{m})$ & 3.281 & foot $(\mathrm{ft})$ \\
\hline meter $(\mathrm{m})$ & 1.094 & yard (yd) \\
\hline \multicolumn{3}{|c|}{ Area } \\
\hline acre & 4,047 & square meter $\left(\mathrm{m}^{2}\right)$ \\
\hline acre & 0.4047 & hectare (ha) \\
\hline acre & 0.4047 & square hectometer $\left(\mathrm{hm}^{2}\right)$ \\
\hline acre & 0.004047 & square kilometer $\left(\mathrm{km}^{2}\right)$ \\
\hline square mile $\left(\mathrm{mi}^{2}\right)$ & 259.0 & hectare (ha) \\
\hline square mile $\left(\mathrm{mi}^{2}\right)$ & 2.590 & square kilometer $\left(\mathrm{km}^{2}\right)$ \\
\hline
\end{tabular}

\section{Abbreviations}

$\begin{array}{ll}\text { Camp Lejeune } & \text { U.S. Marine Corps Base Camp Lejeune } \\ \text { CBLCM } & \text { Chesapeake Bay Land-Change Model } \\ \text { DOD } & \text { Department of Defense } \\ \text { FAO } & \text { Food and Agriculture Organization of the United Nations } \\ \text { NCOBM } & \text { North Carolina Office of Budget and Management } \\ \text { NOAA-CCAP } & \text { National Oceanic and Atmospheric Administration-Coastal Change Analysis Program } \\ \text { SERPPAS } & \text { Southeast Regional Partnership for Planning and Sustainability } \\ \text { USGS } & \text { U.S. Geological Survey }\end{array}$





\title{
Historic and Forecasted Population and Land-Cover Change in Southeastern North Carolina, 1992-2030
}

\author{
By Peter R. Claggett, Paul P. Hearn, Jr., and David I. Donato
}

\section{Introduction}

The Southeast Regional Partnership for Planning and Sustainability (SERPPAS) was formed in 2005 as a partnership between the Department of Defense (DOD) and State and Federal agencies to promote better collaboration in making resource-use decisions. In support of this goal, the U.S. Geological Survey (USGS) conducted a study to evaluate historic population growth and landcover change, and to model future change, for the 13-county SERPPAS study area in southeastern North Carolina (fig. 1). Improved understanding of trends in land-cover change and the ability to forecast land-cover change that is consistent with these trends will be a key component of efforts to accommodate local military-mission imperatives while also promoting sustainable economic growth throughout the 13-county study area.

The study had three principal objectives:

1. Evaluate historic changes in population and land cover for the period 1992-2006 using both previously existing as well as newly generated land-cover data.

2. Develop models to forecast future change in land cover using the data gathered in objective 1 in conjunction with ancillary data on the suitability of the various sub-areas within the study area for low- and high-intensity urban development.

3. Deliver these results - including an executive-level briefing and a USGS technical reportto DOD, other project cooperators, and local counties in hard-copy and digital formats and via the Web through a map-based data viewer.

This report provides a general overview of the study and is intended for general distribution to non-technical audiences.

\section{Historic and Forecasted Population Change}

The study area consists of 13 counties in southeastern (coastal) North Carolina: Beaufort, Brunswick, Carteret, Columbus, Craven, Duplin, Jones, Lenoir, New Hanover, Onslow, Pamlico, Pender, and Wayne. The area is mostly rural, dominated by forests and wetlands. Data from the North Carolina Office of Budget and Management (NCOBM) show that prior to the 1992 start of this study's period of interest, substantial population growth had occurred in Onslow County following the founding of the U.S. Marine Corps Base Camp Lejeune (Camp Lejeune) in 1941, with continued rapid growth from 1940 to 1990 (fig. 2). During the 1990s, however, the population of Onslow County remained unchanged, though growth resumed around the year 2000. The NCOBM projected modest future urban growth in the 13-county area, mostly concentrated in the coastal counties to the south (fig. 3 ). In the mid-2000s, additional population growth in the region was anticipated from planned increases in military and associated personnel at Camp Lejeune, and at the Cherry Point and New River Air Stations.

The NCOBM population estimates and projections indicate that the population of Onslow County is expected to increase by an additional 20,000 from 2010 to 2030. Additional growth in the 
military population was expected owing to the Grow the Force Initiative. Counties with the highest projected population growth rates from 2010 to 2030 are Brunswick ( 58 percent), Pender (45 percent), New Hanover (37 percent), and Duplin (23 percent). Growth in New Hanover County is focused around the city of Wilmington, and growth in Brunswick County is focused around its oceanshore communities. Through the year 2030, the three fastest-growing counties are expected to be New Hanover (74,696 projected new residents), Brunswick (64,921 projected new residents), and Pender (24,526 projected new residents). By contrast, population in Columbus, Jones, Lenoir, and Pamlico Counties is expected to decline.

\section{Historic Land-Cover Change (1992-2006)}

Note: The terms "land cover" and "land use" are often confused with one another. Land use is the human use of land. Land use often involves the management and modification of land from its natural or prior state into a developed state, with buildings, roads, and other human-made structures; or into fields, pastures, parks, or other human-influenced states. Land use also has been defined as "the arrangements, activities and inputs people undertake in a certain land cover type to produce, change or maintain it" (Di Gregorio, 2005). Land cover, on the other hand, is defined as "the observed (bio)physical cover on the earth's surface" (Di Gregorio, 2005).

While the historic and projected growth data shown previously provide a useful regional picture of how population is changing over time, planning for future development at the county or municipal level requires more detailed information. As a first step in addressing this need, personnel involved in this study worked with the National Oceanic and Atmospheric Administration-Coastal Change Analysis Program (NOAA-CCAP) to develop maps of land cover for the 13-county study area for the target dates 1992, 1996, 2001, and 2006. Derived from Landsat satellite imagery, the maps have a spatial resolution of 30 meters (m). The 1996 and 2001 datasets were already in hand; the 1992 and 2006 datasets were added by this study to support and improve the quality of the land-change modeling effort. All 4 datasets originally included 22 classes of land cover, but for clarity in reporting and visualizing land-cover change trends, the data were reclassified into 9 aggregated land-cover classes (tables 1 and 2 and fig. 4). 
Table 1. Land-cover classes for southeastern North Carolina created by aggregating relevant classes defined for the National Oceanic and Atmospheric Administration's Coastal Change Analysis Program (NOAA-CCAP).

\begin{tabular}{|c|c|}
\hline Relevant CCAP Land-Cover Classes & Aggregated Land-Cover Classes Used in This Study \\
\hline High Intensity Developed & \multirow{2}{*}{ High Intensity Urban } \\
\hline Medium Intensity Developed & \\
\hline Low Intensity Developed & \multirow{2}{*}{ Low Intensity Urban } \\
\hline Developed Open Space & \\
\hline Cultivated Land & \multirow{2}{*}{ Agriculture } \\
\hline Pasture Hay & \\
\hline Grassland & \multirow{4}{*}{ Grass/Scrub/Shrub } \\
\hline Scrub/Shrub & \\
\hline Palustrine Scrub/Shrub Wetland & \\
\hline Estuarine Scrub/Shrub Wetland & \\
\hline Deciduous Forest & \multirow{5}{*}{ Forest } \\
\hline Evergreen Forest & \\
\hline Mixed Forest & \\
\hline Palustrine Forested Wetland & \\
\hline Estuarine Forested Wetland & \\
\hline Palustrine Emergent Wetland & \multirow[b]{2}{*}{ Emergent Wetland } \\
\hline Estuarine Emergent Wetland & \\
\hline Bare Land & Barren \\
\hline Water & Water \\
\hline Unconsolidated Shore & \multirow{3}{*}{ Other } \\
\hline Palustrine Aquatic Bed & \\
\hline Estuarine Aquatic Bed & \\
\hline
\end{tabular}


Table 2. Land-cover change sub-tables for southeastern North Carolina: 1992-96, 1996-2001, and 2001-6.

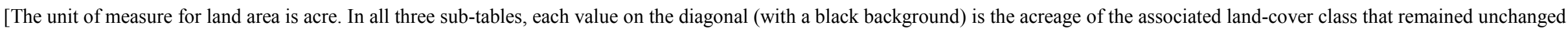

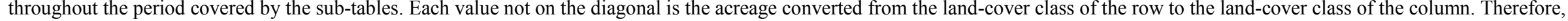

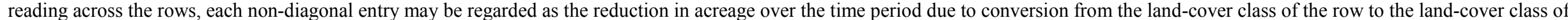

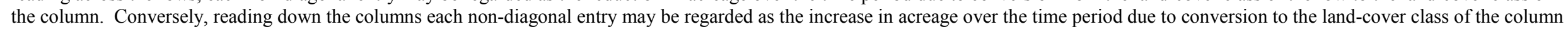
from the land-cover class of the row. For example, reading down the column for the Low Intensity Urban class in the 1992-96 sub-table: 843 acres of Agriculture; 10,485 acres of

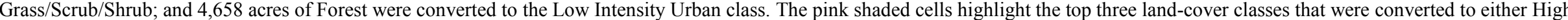
Intensity Urban or Low Intensity Urban in each time period]

\begin{tabular}{|c|c|c|c|c|c|c|c|c|c|c|c|}
\hline & & \multicolumn{9}{|c|}{1996} & \multirow[b]{2}{*}{1992 Total } \\
\hline & & $\begin{array}{l}\text { High } \\
\text { Intensity } \\
\text { Urban }\end{array}$ & $\begin{array}{c}\text { Low } \\
\text { Intensity } \\
\text { Urban }\end{array}$ & Agriculture & $\begin{array}{c}\text { Grass/Scrub/ } \\
\text { Shrub }\end{array}$ & Forest & $\begin{array}{l}\text { Emergent } \\
\text { Wetland }\end{array}$ & Barren & Water & Other & \\
\hline \multirow{10}{*}{1992} & $\begin{array}{l}\text { High Intensity } \\
\text { Urban }\end{array}$ & 31,653 & 0 & 0 & 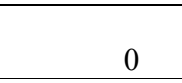 & 0 & 0 & 3 & 0 & 0 & 31,657 \\
\hline & $\begin{array}{l}\text { Low Intensity } \\
\text { Urban }\end{array}$ & 95 & 204,471 & 0 & 0 & 0 & 0 & 33 & 0 & 0 & 204,599 \\
\hline & Agriculture & 148 & 843 & $1,167,384$ & 2,576 & 3,589 & 180 & 2,120 & 429 & 6 & $1,177,276$ \\
\hline & Grass/Scrub/Shrub & 1,204 & 10,485 & 8,781 & 747,935 & 223,647 & 1,105 & 722 & 736 & 22 & 994,636 \\
\hline & Forest & 549 & 4,658 & 13,066 & 159,858 & $2,430,457$ & 8,906 & 600 & 582 & 12 & $2,618,688$ \\
\hline & Emergent Wetland & 22 & 153 & 1,190 & 20,476 & 19,051 & 148,672 & 198 & 326 & 3 & 190,091 \\
\hline & Barren & 23 & 181 & 32 & 398 & 108 & 20 & 20,111 & 318 & 32 & 21,224 \\
\hline & Water & 8 & 49 & 15 & 147 & 92 & 96 & 1,370 & 94,824 & 47 & 96,647 \\
\hline & Other & 0 & 3 & 0 & 6 & 12 & 2 & 76 & 42 & 3,513 & 3,655 \\
\hline & 1996 Total & 33,703 & 220,844 & $1,190,467$ & 931,396 & $2,676,956$ & 158,980 & 25,233 & 97,257 & 3,635 & $5,338,474$ \\
\hline
\end{tabular}




\begin{tabular}{|c|c|c|c|c|c|c|c|c|c|c|c|}
\hline & & \multicolumn{9}{|c|}{2001} & \multirow[b]{2}{*}{1996 Total } \\
\hline & & $\begin{array}{c}\text { High } \\
\text { Intensity } \\
\text { Urban }\end{array}$ & $\begin{array}{c}\text { Low } \\
\text { Intensity } \\
\text { Urban }\end{array}$ & Agriculture & $\begin{array}{c}\text { Grass/Scrub/ } \\
\text { Shrub }\end{array}$ & Forest & $\begin{array}{l}\text { Emergent } \\
\text { Wetland }\end{array}$ & Barren & Water & Other & \\
\hline \multirow{10}{*}{1996} & $\begin{array}{l}\text { High Intensity } \\
\text { Urban }\end{array}$ & 33,703 & 0 & s. & 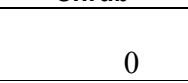 & 0 & Mngm & 0 & 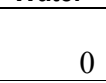 & 0 & 33,703 \\
\hline & $\begin{array}{l}\text { Low Intensity } \\
\text { Urban }\end{array}$ & 0 & 220,844 & 0 & 0 & 0 & 0 & 0 & 0 & 0 & 220,844 \\
\hline & Agriculture & 41 & 1,127 & $1,188,813$ & 380 & 49 & 3 & 20 & 35 & 0 & $1,190,467$ \\
\hline & Grass/Scrub/Shrub & 97 & 4,127 & 1,231 & 813,771 & 104,756 & 5,674 & 692 & 1,044 & 5 & 931,396 \\
\hline & Forest & 313 & 7,301 & 14,095 & 346,255 & $2,288,241$ & 17,453 & 1,269 & 1,933 & 96 & $2,676,956$ \\
\hline & Emergent Wetland & 1 & 10 & 151 & 8,009 & 4,092 & 146,075 & 125 & 510 & 8 & 158,980 \\
\hline & Barren & 45 & 113 & 0 & 945 & 80 & 295 & 22,647 & 908 & 200 & 25,233 \\
\hline & Water & 8 & 41 & 98 & 884 & 358 & 895 & 492 & 94,327 & 155 & 97,257 \\
\hline & Other & 0 & 4 & 4 & 14 & 3 & 37 & 94 & 160 & 3,320 & 3,635 \\
\hline & 2001 Total & 34,209 & 233,567 & $1,204,392$ & $1,170,258$ & $2,397,578$ & 170,432 & 25,338 & 98,916 & 3,784 & $5,338,474$ \\
\hline
\end{tabular}

\begin{tabular}{|c|c|c|c|c|c|c|c|c|c|c|c|}
\hline & & \multicolumn{9}{|c|}{2006} & \multirow[b]{2}{*}{2001 Total } \\
\hline & & $\begin{array}{c}\text { High } \\
\text { Intensity } \\
\text { Urban }\end{array}$ & $\begin{array}{c}\text { Low } \\
\text { Intensity } \\
\text { Urban }\end{array}$ & Agriculture & $\begin{array}{c}\text { Grass/Scrub/ } \\
\text { Shrub }\end{array}$ & Forest & $\begin{array}{l}\text { Emergent } \\
\text { Wetland }\end{array}$ & Barren & Water & Other & \\
\hline \multirow{10}{*}{2001} & $\begin{array}{l}\text { High Intensity } \\
\text { Urban }\end{array}$ & 34,173 & 24 & 50 & 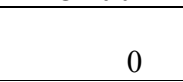 & 0 & 0 & - & 12 & 0 & 34,209 \\
\hline & $\begin{array}{l}\text { Low Intensity } \\
\text { Urban }\end{array}$ & 907 & 232,588 & 0 & 26 & 0 & 0 & 0 & 46 & 0 & 233,567 \\
\hline & Agriculture & 1,205 & 828 & $1,200,895$ & 687 & 0 & 64 & 95 & 618 & 0 & $1,204,392$ \\
\hline & Grass/Scrub/Shrub & 573 & 906 & 1,451 & $1,138,903$ & 12,635 & 6,972 & 7,993 & 824 & 0 & $1,170,258$ \\
\hline & Forest & 808 & 1,323 & 22 & 194,640 & $2,176,603$ & 16,435 & 7,463 & 284 & 0 & $2,397,578$ \\
\hline & Wetland & 9 & 12 & 0 & 1,583 & 5,141 & 163,666 & 0 & 20 & 0 & 170,432 \\
\hline & Barren & 28 & 25 & 0 & 130 & 0 & 0 & 23,486 & 1,612 & 56 & 25,338 \\
\hline & Water & 14 & 4 & 28 & 151 & 0 & 50 & 370 & 98,244 & 55 & 98,916 \\
\hline & Other & 0 & 0 & 0 & 8 & 0 & 0 & 173 & 46 & 3,557 & 3,784 \\
\hline & 2006 Total & 37,718 & 235,710 & $1,202,396$ & $1,336,127$ & $2,194,379$ & 187,187 & 39,580 & 101,708 & 3,669 & $5,338,474$ \\
\hline
\end{tabular}


During each of the three change periods considered in the study, 1992-96, 1996-2001, and 2001-6, less than 10 percent of the landscape changed from one class to another (figs. 5 and 6). Change was greatest during the 1996-2001 period when change occurred on 9.87 percent of the land area (table 3 and fig. 7). The majority of observed change during all three periods resulted from forest transitioning to grass or scrub/shrub and vice versa (tables 2, 4, and 5). Transitions to urban development are highlighted in pink in table 2. Over the 13-year observational record, urban area increased to more than 37,000 acres (tables 4 and 6), mostly associated with the development of grass/scrub/shrub, and forested areas rather than with the development of agricultural areas.

Table 3. Total amount of land in the study area that changed from one land-cover class to another during each of three time periods. The land area of the entire study area is 5,338,474 acres.

\begin{tabular}{lcc}
\hline \multicolumn{1}{c}{ Time period } & Total acreage converted & $\begin{array}{c}\text { Percent of study area changing } \\
\text { land-cover class }\end{array}$ \\
\hline 1992-96 & 489,451 & 9.17 \\
\hline 1996-2001 & 526,735 & 9.87 \\
\hline 2001-6 & 266,356 & 4.99 \\
\hline
\end{tabular}

Table 4. Summary of absolute and percentage net change in land cover by land-cover class in southeastern North Carolina during 1992-2006. The unit of measure for land area is the acre.

\begin{tabular}{lrrrrrr}
\hline \multicolumn{1}{c}{ Land-Cover Class } & \multicolumn{1}{c}{1992} & 1996 & $\mathbf{2 0 0 1}$ & $\mathbf{2 0 0 6}$ & $\begin{array}{c}\text { Net change } \\
\text { (acres) }\end{array}$ & $\begin{array}{c}\text { Net change } \\
\text { (percent) }\end{array}$ \\
\hline High Intensity Urban & 31,657 & 33,703 & 34,209 & 37,718 & $+6,062$ & +19.1 \\
\hline Low Intensity Urban & 204,599 & 220,844 & 233,567 & 235,710 & $+31,111$ & +15.2 \\
\hline Agriculture & $1,177,276$ & $1,190,467$ & $1,204,392$ & $1,202,396$ & $+25,120$ & +2.1 \\
\hline Grass/Scrub/Shrub & 994,636 & 931,396 & $1,170,258$ & $1,336,127$ & $+341,490$ & +34.3 \\
\hline Forest & $2,618,688$ & $2,676,956$ & $2,397,578$ & $2,194,379$ & $-424,309$ & -16.2 \\
\hline Emergent Wetland & 190,091 & 158,980 & 170,432 & 187,187 & $-2,905$ & +1.5 \\
\hline Barren & 21,224 & 25,233 & 25,338 & 39,580 & $+18,357$ & +86.5 \\
\hline Water & 96,647 & 97,257 & 98,916 & 101,708 & $+5,060$ & +13 \\
\hline Other & 3,655 & 3,635 & 3,784 & 3,669 & & +5.2 \\
\hline
\end{tabular}


Table 5. Change in acreage by land-cover class for each of three time periods in the southeastern North Carolina study area. For each land-cover class in each time period acreage increased due to conversion to the land-cover class from other classes, but acreage also decreased due to conversion to other landcover classes; the net change is the difference between the increase and the decrease.

\begin{tabular}{|c|c|c|c|c|c|c|c|c|c|}
\hline \multirow[b]{2}{*}{ Land-Cover Class } & \multicolumn{3}{|c|}{ 1992-96 } & \multicolumn{3}{|c|}{ 1996-2001 } & \multicolumn{3}{|c|}{ 2001-06 } \\
\hline & Increase & Decrease & Net change & Increase & Decrease & Net change & Increase & Decrease & Net change \\
\hline High Intensity Urban & 2,049 & 3 & 2,046 & 505 & 0 & 505 & 3,544 & 36 & 3,508 \\
\hline Low Intensity Urban & 16,372 & 128 & 16,244 & 12,723 & 0 & 12,723 & 3,122 & 979 & 2,143 \\
\hline Agriculture & 23,084 & 9,891 & 13,193 & 15,579 & 1,655 & 13,924 & 1,501 & 3,497 & $-1,996$ \\
\hline Grass/Scrub/Shrub & 183,461 & 246,702 & $-63,241$ & 356,487 & 117,626 & 238,861 & 197,225 & 31,354 & 165,871 \\
\hline Forest & 246,499 & 188,231 & 58,268 & 109,338 & 388,715 & $-279,377$ & 17,776 & 220,975 & $-203,199$ \\
\hline Emergent Wetland & 10,309 & 41,419 & $-31,110$ & 24,357 & 12,906 & 11,451 & 23,521 & 6,765 & 16,756 \\
\hline Barren & 5,122 & 1,112 & 4,010 & 2,692 & 2,586 & 106 & 16,094 & 1,851 & 14,243 \\
\hline Water & 2,433 & 1,824 & 609 & 4,590 & 2,931 & 1,659 & 3,462 & 672 & 2,790 \\
\hline Other & 122 & 141 & -19 & 464 & 316 & 148 & 111 & 227 & -116 \\
\hline
\end{tabular}

Table 6. Acres and percent of the total land area of the study area in southeastern North Carolina at four points in time. The sum of the acres columns for 1992 and 1996 do not equal the exact total acreage of the study area $(5,338,474)$ because of rounding.

\begin{tabular}{|c|c|c|c|c|c|c|c|c|}
\hline \multirow[b]{2}{*}{ Land-Cover Class } & \multicolumn{2}{|c|}{1992} & \multicolumn{2}{|c|}{1996} & \multicolumn{2}{|c|}{2001} & \multicolumn{2}{|c|}{2006} \\
\hline & Acres & $\begin{array}{l}\text { Percent of land } \\
\text { area }\end{array}$ & Acres & $\begin{array}{c}\text { Percent of land } \\
\text { area }\end{array}$ & Acres & $\begin{array}{l}\text { Percent of land } \\
\text { area }\end{array}$ & Acres & $\begin{array}{l}\text { Percent of land } \\
\text { area }\end{array}$ \\
\hline High Intensity Urban & 31,657 & 0.59 & 33,703 & 0.63 & 34,209 & 0.64 & 37,718 & 0.71 \\
\hline Low Intensity Urban & 204,599 & 3.83 & 220,844 & 4.14 & 233,567 & 4.38 & 235,710 & 4.42 \\
\hline Agriculture & $1,177,276$ & 22.05 & $1,190,467$ & 22.30 & $1,204,392$ & 22.56 & $1,202,396$ & 22.52 \\
\hline Grass/Scrub/Shrub & 994,636 & 18.63 & 931,396 & 17.45 & $1,170,258$ & 21.92 & $1,336,127$ & 25.03 \\
\hline Forest & $2,618,688$ & 49.05 & $2,676,956$ & 50.14 & $2,397,578$ & 44.91 & $2,194,379$ & 41.10 \\
\hline Emergent Wetland & 190,091 & 3.56 & 158,980 & 2.98 & 170,432 & 3.19 & 187,187 & 3.51 \\
\hline Barren & 21,224 & 0.40 & 25,233 & 0.47 & 25,338 & 0.47 & 39,580 & 0.74 \\
\hline Water & 96,647 & 1.81 & 97,257 & 1.82 & 98,916 & 1.85 & 101,708 & 1.91 \\
\hline Other & 3,655 & 0.07 & 3,635 & 0.07 & 3,784 & 0.07 & 3,669 & 0.07 \\
\hline
\end{tabular}




\section{Forecasting Land-Cover Change}

From the early years of land-cover change science, the USGS has played a lead role in measuring and forecasting land change at the national and regional scales. Under the USGS Urban Dynamics research program, USGS researchers have authored and contributed to studies that assessed the causes and consequences of urban growth and simulated urban growth into the future (Clarke and others, 1997; Auch and others, 2004; Acevedo and others, 2006). USGS researchers and collaborating partners have built on this work and developed the Chesapeake Bay Land-Change Model, version 1 (CBLCM_v1) to inform State and Federal restoration decisions in the Chesapeake Bay Watershed. The CBLCM_v1 combines the strengths of a growth-allocation model, based on GAMe (Reilly, 2003), with those of a cellular-automata model, SLEUTH (slope, land use, excluded land, urban extent, transportation, and hillshade) (Clarke and others, 1997; Jantz and others, 2004), to simulate future urban growth throughout the 64,000 square mile $\left(\mathrm{mi}^{2}\right)$ Chesapeake Bay Watershed. GAMe is used to convert county population forecasts into urban footprints assigned to small watersheds. SLEUTH utilizes maps of urban growth derived from Landsat satellite imagery to generate maps showing the probability of future urban growth.

For this study, the USGS utilized the GAMe and SLEUTH models to forecast future land change in the 13-county study area at a 30-m cell resolution. (That is, the entire study area was covered by a regular array of rows and columns of $30 \mathrm{~m} \times 30 \mathrm{~m}$ cells.) GAMe was originally developed in the mid-1990s for the New Jersey Office of State Planning to generate municipal-scale forecasts of housing and office-space demand. For the purposes of this study, GAMe was used to (1) translate county-scale population projections produced by NCOBM into estimates of new housing demand, and (2) downscale the housing demand from the County to the Minor Civil Division scale. Given the lack of data on locally available office space, no further attempt was made to forecast future office-space requirements. The NCOBM county-level population projections out to the years 2010, 2020, and 2030 were used as input to GAMe for generating forecasts of housing demand.

SLEUTH is an urban-growth model that forecasts urbanization based on input images for slope (topography), land use, exclusion of land (suitability), historical urbanization, and transportation (especially roads) (http://www.ncgia.ucsb.edu/projects/gig/). SLEUTH output is in the form of a map showing the probability of future growth. Using spatial data on historic urban growth (1992-2006), the SLEUTH model was then used to forecast urban growth (which under the study's modeling approach included suburban and semi-rural residential development). As part of the input to the SLEUTH model, a suitability map was developed identifying areas where growth was prohibited (for example, parks, game preserves, and other State lands) or encouraged (for example, areas designated for development). Developed from data provided by the State, counties, and other sources, this suitability layer was essential in the development of plausible forecasts. Acquiring up-to-date and accurate information for the suitability layer is an ongoing and evolving process that will continue as new growth forecasts are developed in the future (figs. 8 and 9).

GAMe and SLEUTH were run separately from each other, and currently (2015) there is no coded connection between the models. Using spreadsheets, the adjusted urban-area estimates from GAMe were multiplied by the relative proportions of future growth allocated to each land-cover class based on the SLEUTH predictions in order to forecast the amount of new urban growth and of forest and farmland loss within each township.

Calibrating SLEUTH is a computationally intensive process, requiring repeated runs of the model, one for each of thousands of combinations of the calibration parameters. Calibration proceeds from a coarse calibration, in which input parameters are allowed to vary across wide ranges of values, through successively finer calibration runs with narrower ranges of variables. The goal of calibration is to find a set of parameters that enables SLEUTH to match historic rates and patterns of growth. More 
than 30 calibration runs were conducted for this study, making use of the USGS Eastern Geographic Science Center High-Performance Computing Cluster (Beowulf), which allowed us to perform each calibration run to test hundreds or thousands of parameter combinations, generally with a turnaround time for each run of 24 hours or less.

SLEUTH forecasts were based on seven datasets: urban extent and major roads in 1992 and 2006, slope (expressed as a percentage), hillshade, and lands "excluded" from urbanization. The 30-m resolution National Elevation Dataset (http://ned.usgs.gov/) was used to derive percent slope and hillshade. The 1992 and 2006 urban land-cover data were developed by the NOAA-CCAP, and the North Carolina Department of Transportation's Integrated Statewide Road Network provided the static roads data for 1992 and 2006.

The exclusion, or suitability, layer in SLEUTH represents areas partially or completely excluded from development and areas partially or highly attractive to development. The same data used in GAMe to identify lands eligible for development also were used to prepare the SLEUTH suitability layer for the study area of this study. The sub-areas prone to exclusion of development included all protected lands, military lands and facilities, frequently flooded soils, important natural-heritage areas, steep slopes ( $\geq 10$ percent), open water, emergent wetlands, and unconsolidated shorelines. Lands partially suitable for development included residential parcels that are not shown as currently urbanized in the urban land-cover data, which are located within current or future public-sewer service areas, and that cover an area of 5 acres or less.

In prediction mode, SLEUTH's output images match the resolution of the input images. In this study, input images with $30 \mathrm{~m} \times 30 \mathrm{~m}$ cells were used, so the output of a prediction run is a probability map of $30 \mathrm{~m} \times 30 \mathrm{~m}$ cells, with cell values ranging from 0 (never urbanized) to 100 percent (always urbanized). High probability cells are found predominantly around growing urban areas and roads, while low probability cells are found mostly in rural areas. The final SLEUTH output was aggregated into an array of larger $250 \mathrm{~m} \times 250 \mathrm{~m}$ cells (figs. 10 and 11) in order to aid interpretation and presentation. These larger cells were then overlaid on the areas eligible for urban growth to derive statistics on the proportion of agriculture and forest land likely to be converted to urban land-cover classes within each township.

\section{Web-Based Map Viewer}

In addition to the hard and soft copies of historic and forecasted population and land-cover data, this information also will be provided through a Web-based map viewer. The viewer will allow users to view, zoom, pan, print maps, and access project reports (figs. 12 and 13).

\section{Results and Discussion}

SLEUTH model results indicate that most of the population growth in the study area will occur in and around the major cities in the region (such as Wilmington and Jacksonville), along the coast, and around oceanshore communities (figs. $14 A$ and $B$ ). Similar but not identical growth patterns are evident in the map of urban-land demand from the GAMe model (fig. 14C). The differences between the pattern of housing growth produced with SLEUTH and the pattern of demand for urban land produced with GAMe are the result of considering average lot sizes in GAMe. SLEUTH model results do not directly reflect changes in lot size unless those changes are reflected in the land-cover data informing the SLEUTH model. Given the same housing demand in two townships, urban-land demand will be greatest in the township with a larger average residential-lot size. For example, in New Hanover County, the average residential-lot size in Cape Fear township is three times greater than the average residential-lot size in neighboring Harnett township. Demand for urban land (that is, demand for residential-lot acreage) in Cape Fear township is 67 percent higher than in Harnett township despite the 
fact that housing demand in Harnett is 61 percent higher than in Cape Fear. The apparent contradiction goes away with the realization that a smaller number of sufficiently large lots can cover more acreage than a larger number of small lots.

The percent of land available for development within a township or county also must be considered when forecasting how population growth will be specifically distributed among townships and counties. About 63 percent of the developable land area in Harnett township, for example, had been developed prior to the year 2000, compared to only 34 percent in Cape Fear township. In both Harnett and Cape Fear townships, the average future residential-lot size is expected to decrease to half the current average size, based on the modeled regional relationship between average residential-lot size and the percent of land remaining available for development (fig. 14D). The four townships with the highest density factors (Wilmington, Federal Point, Masonboro, and Harnett) are all projected to grow beyond their current capacities of residential land if current average lot sizes remain constant; therefore, either future lot sizes will decrease or growth will be distributed to neighboring townships. Currently (2015), GAMe, as implemented for this study, is not designed to simulate the redistribution of growth among townships.

While the principal subject of (and reason for) this study has been to model urban development near military assets, an important contextual finding has emerged: forestry activities drove the overwhelming majority of land-cover change in the region during the period 1992-2006. The levels of forest clearing and regeneration (forest to grass/scrub/shrub and grass/scrub/shrub to forest) were particularly high throughout the 1990s. During the period 1992-2006, urban growth was highest in the earliest period, 1992-96. The rate and amount of urban growth steadily declined in the latter two periods, 1996-2001 and 2001-6.

Because the SLEUTH urban-growth model was calibrated to match and extrapolate historic patterns of urban change observed during the period 1992-2006, the forecasted urban growth patterns are similar to the actual past urban growth in the study area (figs. $15 B$ and $D$ ). The pattern of forecasted growth was strongly influenced by roads and previously developed areas. The forecasted urban growth patterns reveal that growth surrounding existing military installations, particularly Camp Lejeune and Cherry Point, and within low-altitude flight corridors is expected to continue over the next several decades. Part of the reason for this growth is that these areas are suitable for development (blue areas in figs. $15 \mathrm{~A}$ and $C$ ) in that they are either currently or prospectively served by public sewers or already exhibit evidence of residential use. Future increases in military personnel at these installations will increase the likelihood that surrounding lands will be developed.

The extent of forest, grass/shrubland, and farmland forecasted to be converted to urban development in the study area by 2030 are 72,024 acres, 94,250 acres, and 59,728 acres, respectively. Grass and shrubland are transitional classes created mostly through the clearing of forests and are mostly located near forests. The patterns of forest and farmland loss (figs. 16A-D) are similar to each other because both follow the pattern of forecasted urban growth for the study area. The relative proportions of forest and farmland loss, however, vary because the proportions of forests and farmlands adjacent to existing and growing urban areas are unique for each municipality. For example, the same amount of development in townships in Brunswick, New Hanover, and Craven Counties will probably result in greater declines in forest cover than conversion of farmland, while the same amount of development in townships in Wayne, Duplin, and Carteret Counties is expected to result in more farmland conversion than declines in forest cover. The proportions of grass or shrubland converted to development are not shown because they are closely associated with the patterns of forest loss.

The total amount of GAMe-forecasted urban change that impacts forests, grass/scrub/shrub, or farmlands is 226,000 acres. This is more than double the 98,000 acres of development forecasted with SLEUTH. The amount of development forecasted with SLEUTH corresponds closely to a linear extrapolation of the historical extent of urban change during 1992-2006. The GAMe forecast is substantially higher even though the rate of population growth in the study area is projected to decline. 
The GAMe forecast is higher than the SLEUTH forecast because as discussed above, GAMe uses an estimate of residential-lot size to forecast the extent of urban development. The lot-size estimate is informed by the spatial extent of small parcels ( $\leq 5$ acres), which generally are not represented as urban land in the datasets used to calibrate the SLEUTH model. For this reason, the SLEUTH forecast of urban growth constitutes a conservative estimate. The GAMe forecast, by contrast, provides a more liberal estimate of urban growth especially in those sub-areas of the study area containing large commercial or industrial facilities. The more liberal estimate was used because all urban development, including commercial and industrial areas, represented in the land-cover datasets is assumed in the GAMe model to be proportional to population and represent potential residential lands. Consequently, in a sub-area with few residents and a disproportionate amount of developed land taken up by commercial or industrial facilities, the estimated average residential-lot size will be larger than it is in actuality, and a small forecasted change in population would yield a disproportionate increase in developed land.

\section{Conclusions}

The conclusions of this study are based on maps, land-cover data, and other data and forecasts for the study area. The land-cover data provide a regionally consistent and temporally comparable perspective on how land cover in the 13-county study area changed during the period 1992-2006. The population projections, density factors, and fine-scale forecasts of urban growth identify localized areas where the potential for urban development is most likely to occur.

The suitability-layer map provides a regional perspective on the amount and locations of land available for development, and it illustrates the effect of wastewater policies on patterns of high- and low-intensity urbanization. Through the combination of two urban growth models, GAMe and SLEUTH, the extent of urban development in the study area is forecast to range from 98,000 to 226,000 acres through the year 2030.

The creation and growth of U.S. Marine Corps Base Camp Lejeune starting in the 1940s resulted in substantial population and urban growth, particularly in the Jacksonville area. The rise of tourism and recreation in the 1960s and 1970s and improved road access to coastal counties also has been an important driver of urban growth along the North Carolina coast. The past, however, is not always prologue to the future, as demonstrated by comparing the economic recession that began in 2008 and the associated decline in housing prices with the dot.com boom of the late 1990s and rapid rise of land and housing values during the 2000-6 period. Forecasts of future urban growth can only describe plausible future conditions. Any particular forecast represents just one of many possible future states.

The results of this study provide the foundation for continued U.S. Geological Survey (USGS) efforts to work with other Southeast Regional Partnership for Planning and Sustainability (SERPPAS) partners and local government agencies to refine growth-forecast methodologies and to generate improved information for local use in planning and managing resources and growth in southeastern North Carolina.

\section{References Cited}

Acevedo, William, Taylor, J.L., Hester, D.J., Mladinich, C.S., and Glavac, Sonya, eds., 2006, Rates, trends, causes, and consequences of urban land-use change in the United States: U.S. Geological Survey Professional Paper 1726, 200 p.

Auch, Roger; Taylor, Janis; and Acevedo, William, 2004, Urban growth in American cities - Glimpses of U.S. urbanization: U.S. Geological Survey Circular 1252, 52 p. 
Clarke, K.C., Hoppen, S., and Gaydos, L., 1997, A self-modifying cellular automaton model of historical urbanization in the San Francisco Bay area: Environment and Planning B-Planning and Design, v. 24, no. 2, p. 247-261.

Di Gregorio, Antonio, 2005, Land cover classification system-Classification concepts and user manual (software version 2): Food and Agriculture Organization (FAO) of the United Nations, Rome; accessed October 14, 2014, at http:/www.fao.org/docrep/008/y7220e/y7220e00.HTM.

Jantz, C.A., Goetz, S.J., and Shelley, M.K., 2004, Using the SLEUTH urban growth model to simulate the impacts of future policy scenarios on urban land use in the Baltimore-Washington metropolitan area: Environment and Planning B-Planning and Design, v. 31, no. 2, p. 251-271.

Reilly, James, 2003, The New Jersey (USA) growth allocation model-Development, evaluation and extension, in Geertman, Stan, and Stillwell, John, eds., Planning support systems in practiceAdvances in spatial science: Springer, chap. 20, p. 373-389, available online at http://link.springer.com/book/10.1007/978-3-540-24795-1/page/1. 


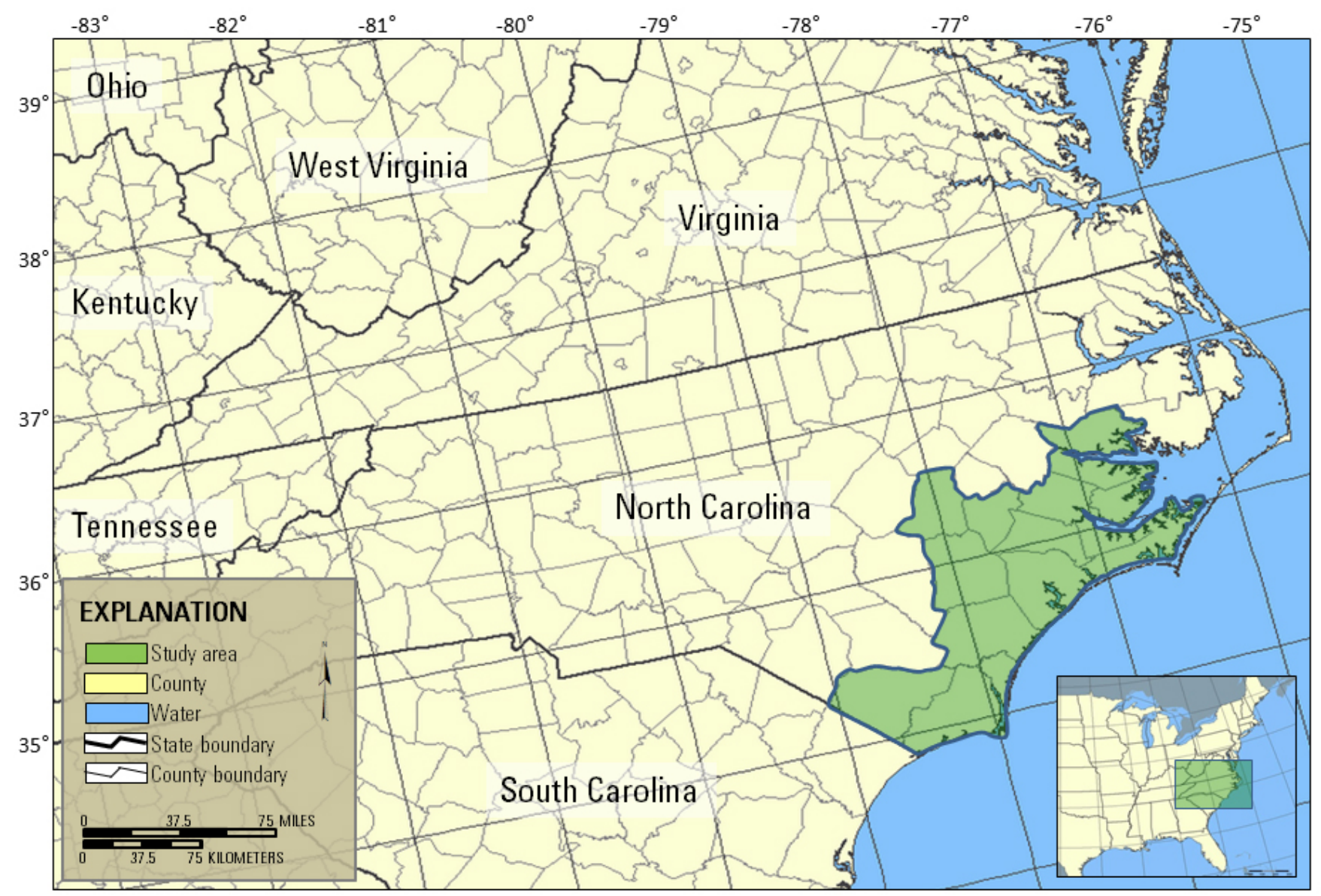

Figure 1. Map showing the 13-county study area in southeastern North Carolina.

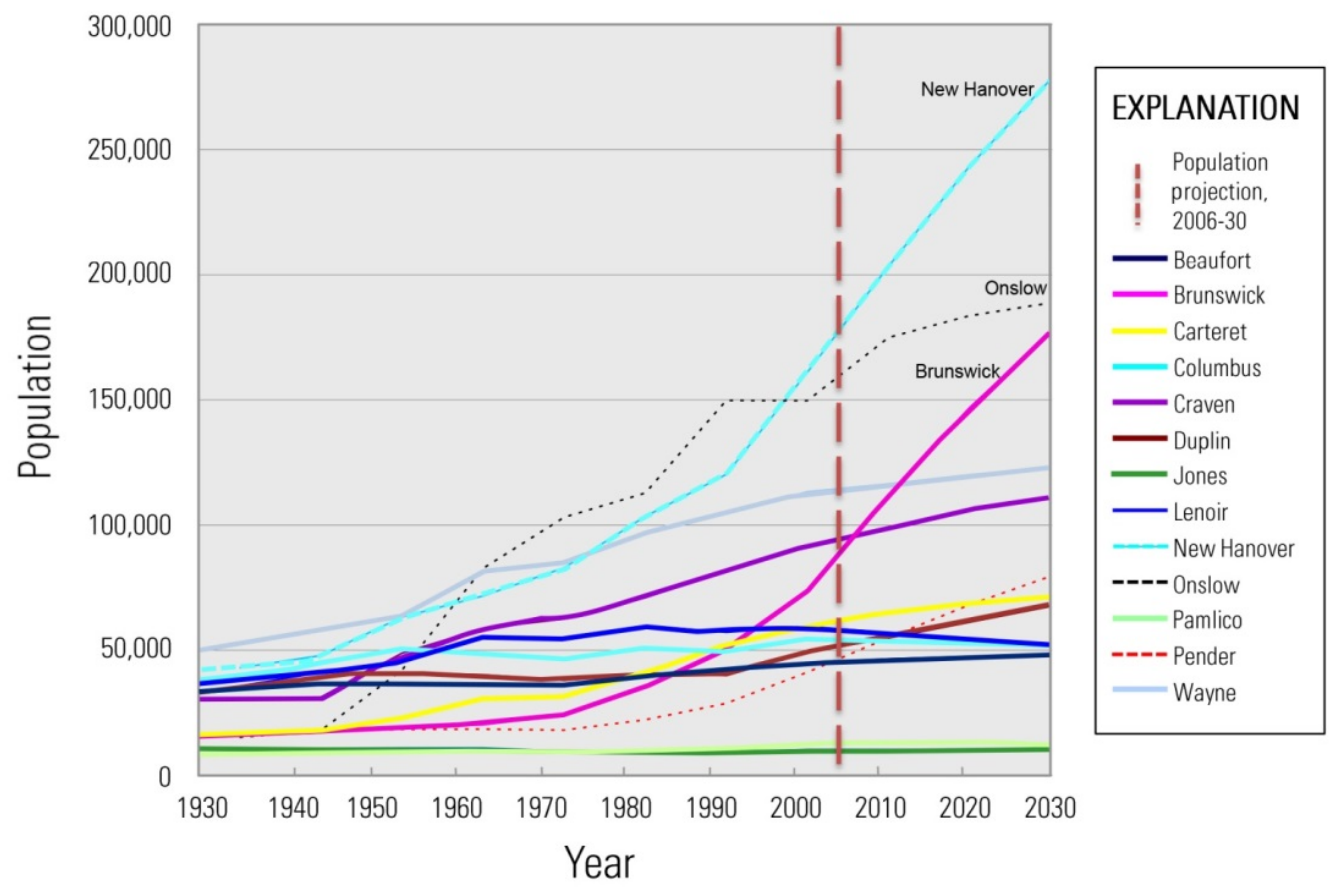

Figure 2. Historic and projected population growth in the 13-county study area, southeastern North Carolina. 


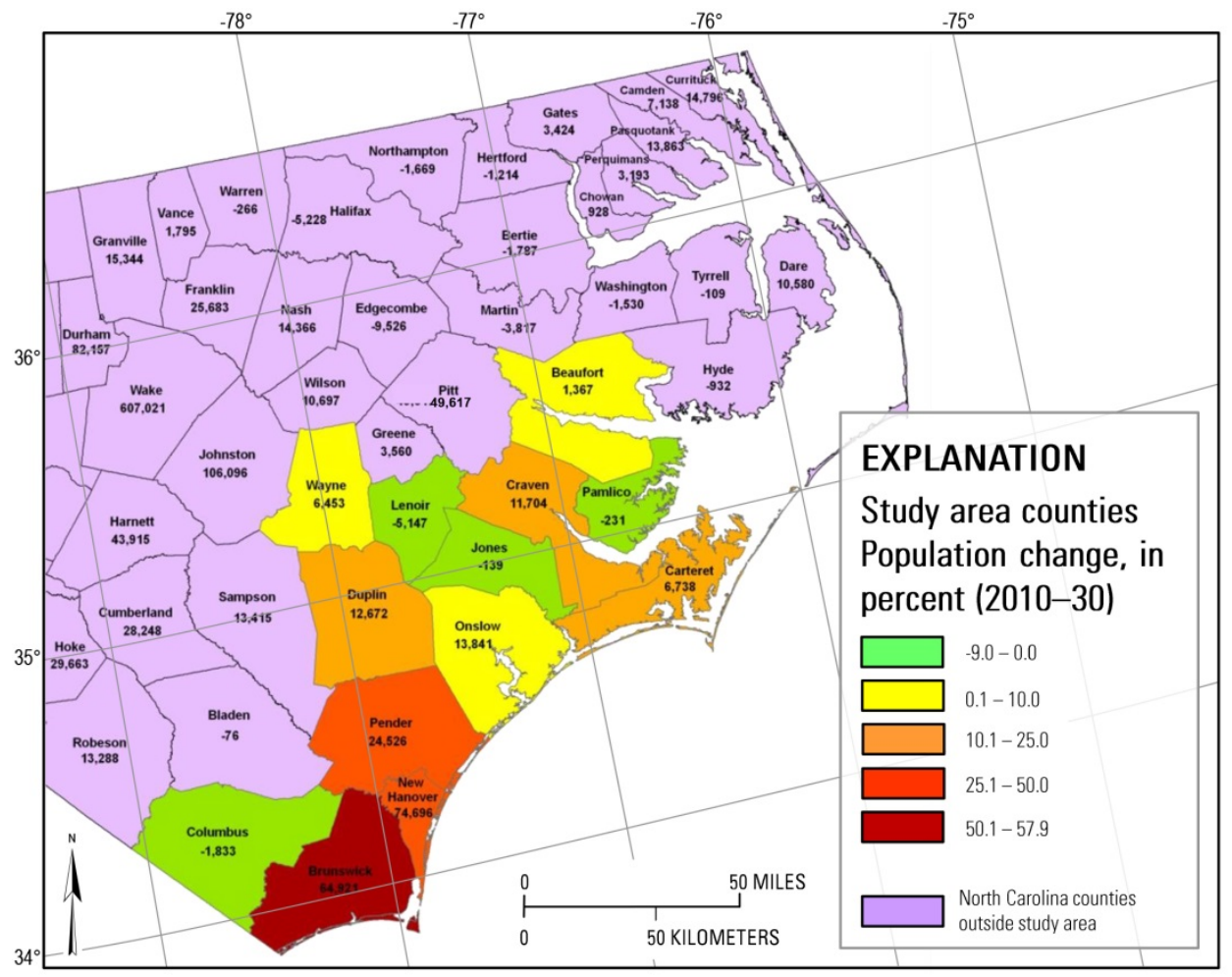

Figure 3. Projected population change for the period 2010-30 in the 13-county study area, southeastern North Carolina. Projected absolute change in population is shown on the map within each county. (Source: North Carolina Office of State Budget and Management).

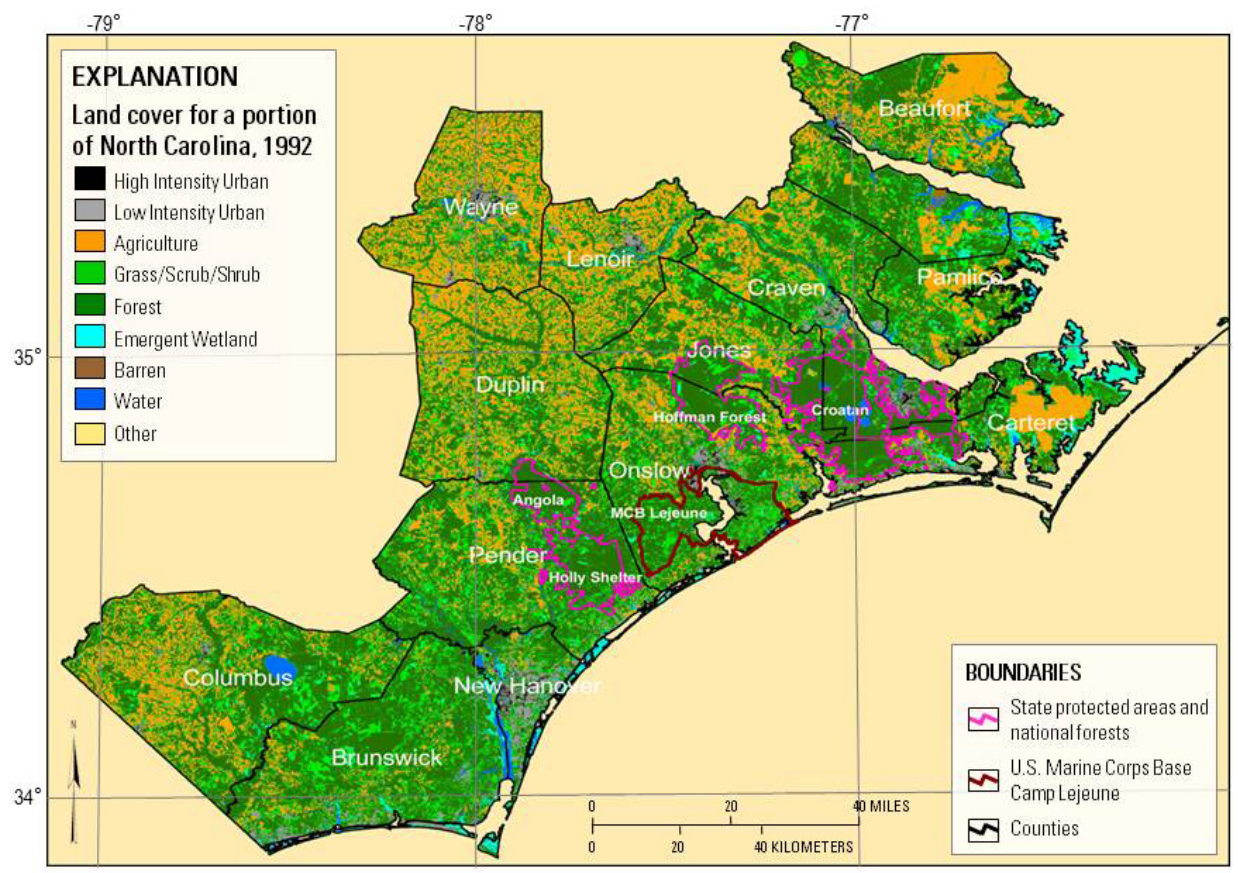

Figure 4. Land-cover map for a portion of North Carolina, 1992 (aggregated to nine classes from National Oceanic and Atmospheric Administration-Coastal Change Analysis Program data). Maroon line designates boundary of U.S. Marine Corps Base Camp Lejeune; magenta lines designate State-protected areas. 


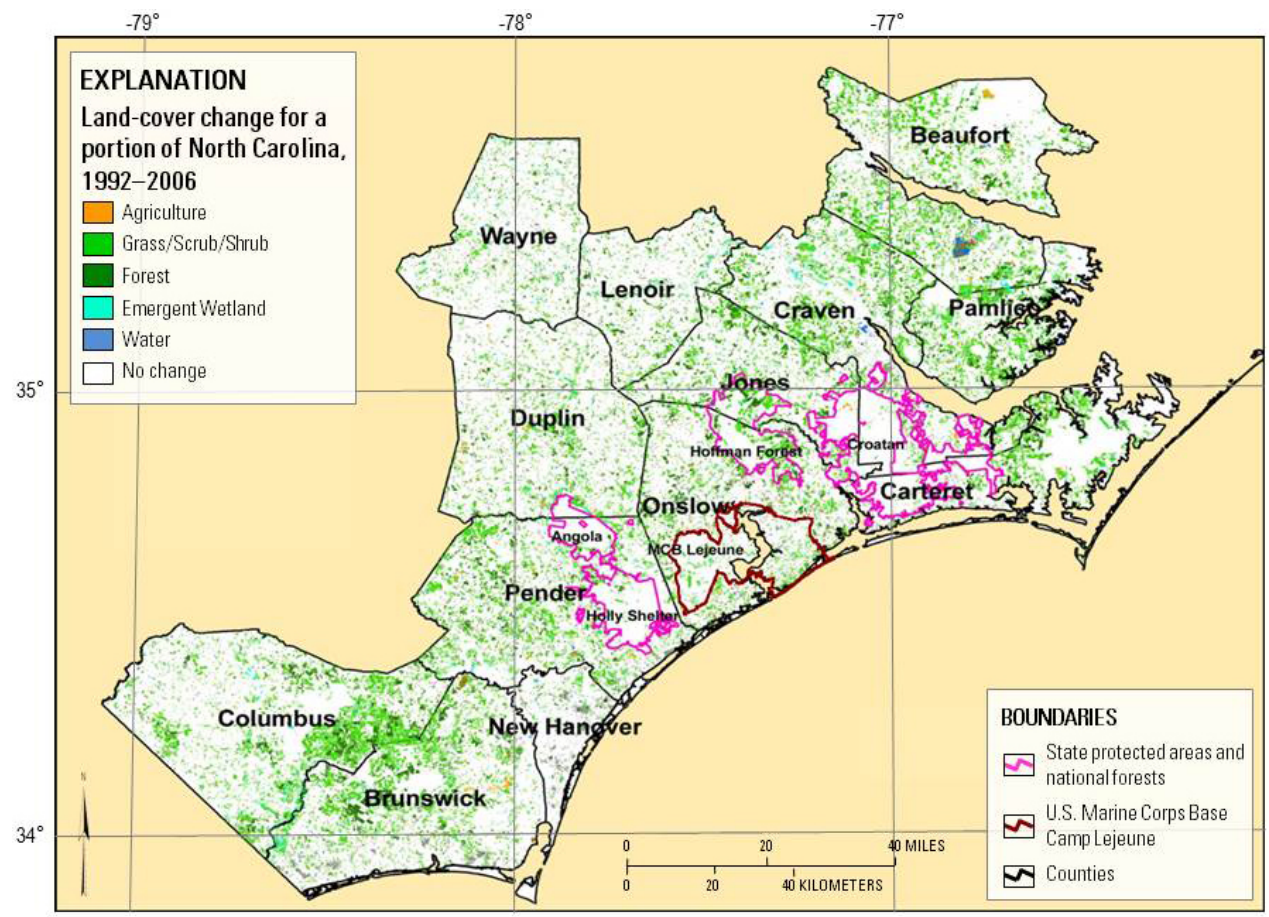

Figure 5. Areas of land-cover change for a portion of North Carolina, 1992-2006 (aggregated to nine classes from National Oceanic and Atmospheric AdministrationCoastal Change Analysis Program data). Magenta lines designate boundaries of protected areas managed by the North Carolina Wildlife Resources Commission. Maroon lines designate the boundary of U.S. Marine Corps Base Camp Lejeune.

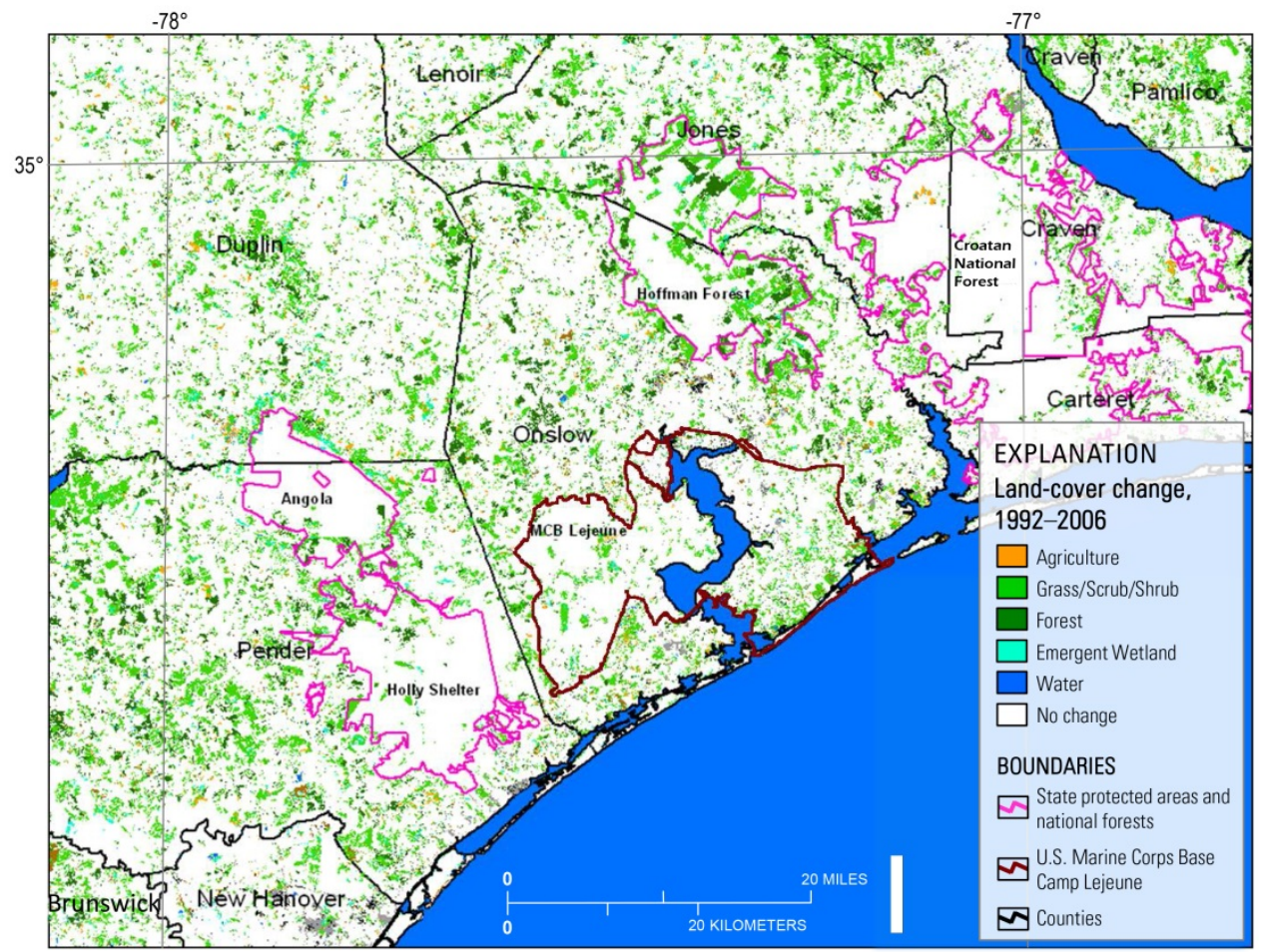

Figure 6. Detail from figure 5 showing land-cover change in Onslow and surrounding counties, North Carolina, 1992-2006. 


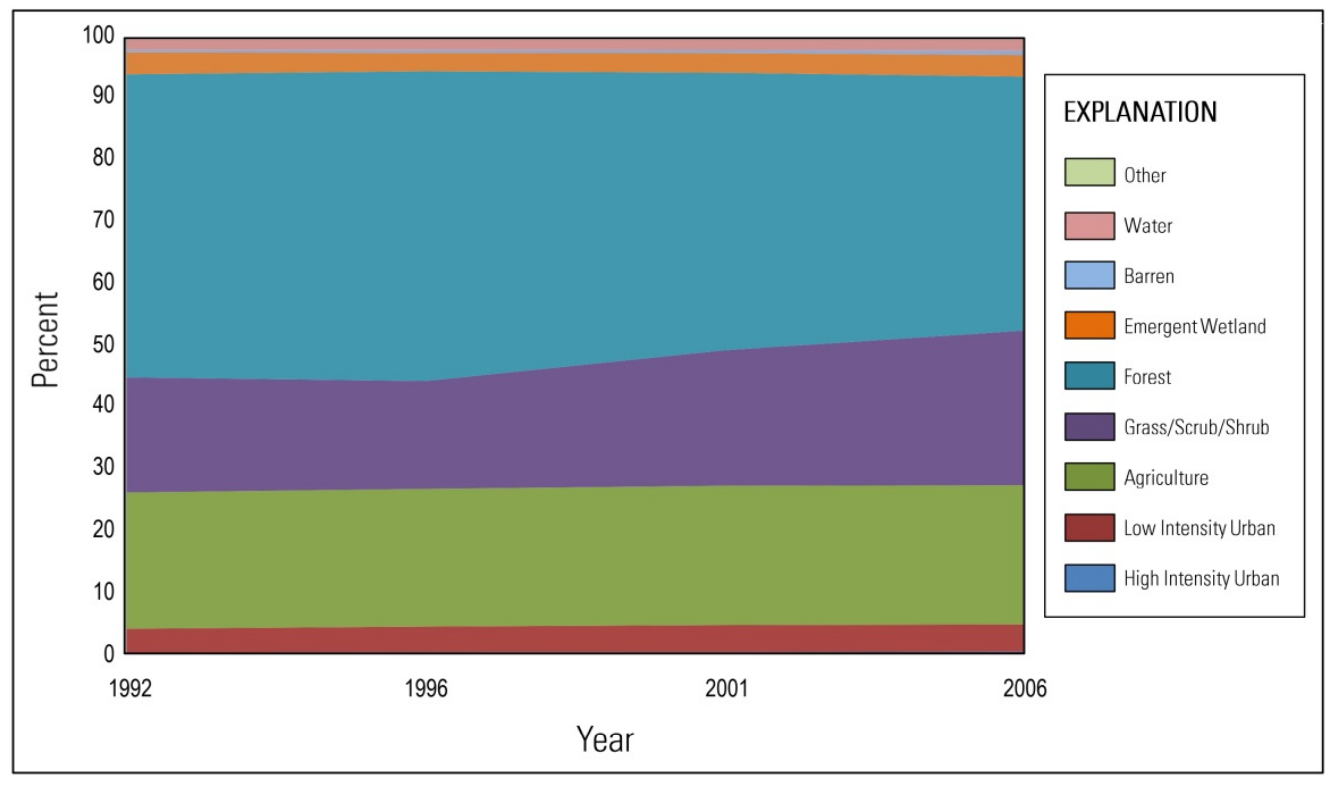

Figure 7. Changes over time of the relative proportions of the nine aggregated landcover types in the southeastern North Carolina study area. The bottom layer of this chart for High Intensity Urban is difficult to see because High Intensity Urban makes up such a relatively small proportion of overall land cover in the study area.

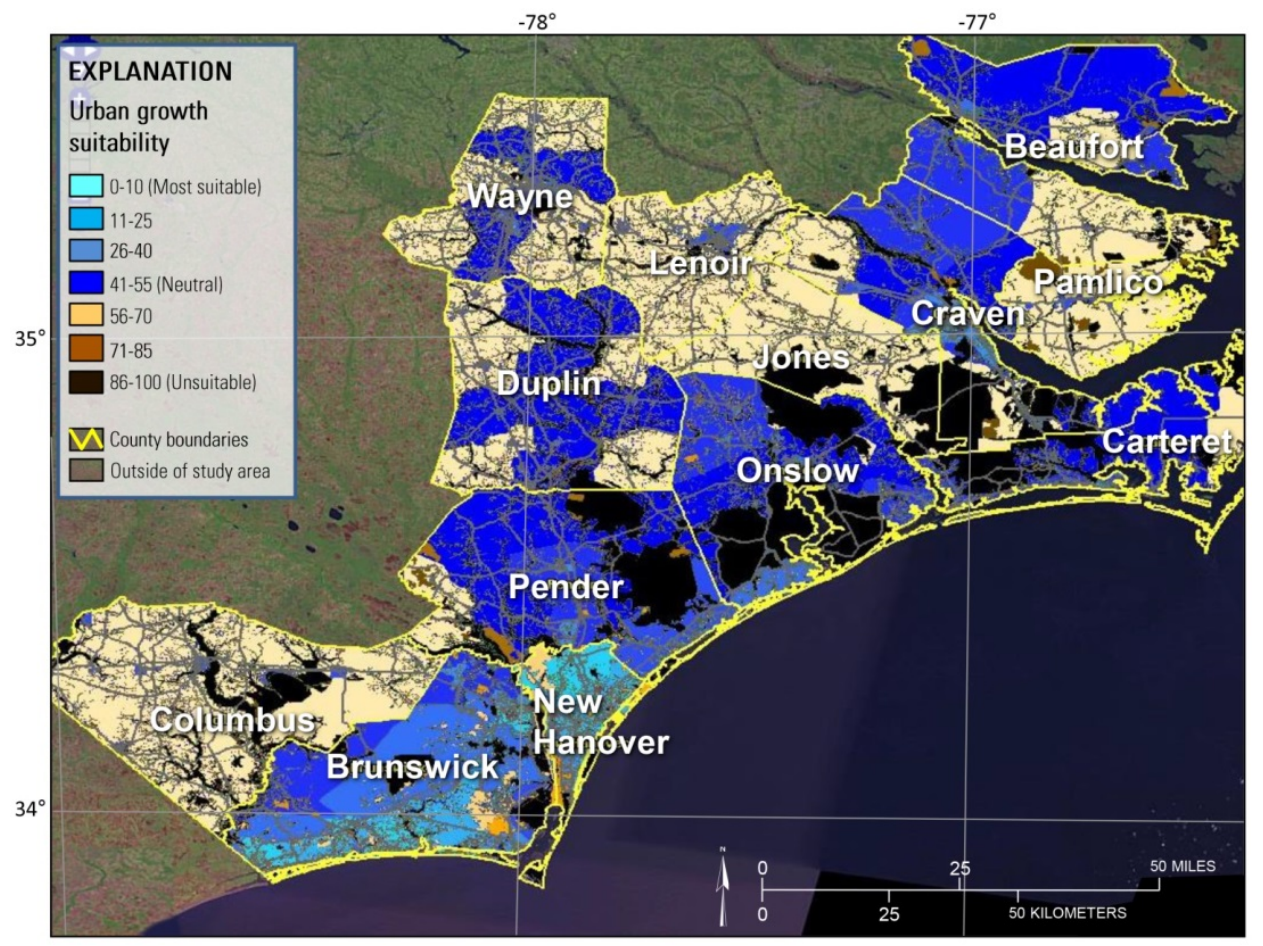

Figure 8. Relative suitability for urban growth in southeastern North Carolina. Shades of blue from dark to light indicate moderate to high suitability for growth. Beige areas are neutral. Shades of brown to black indicate areas increasingly unsuitable for growth. 


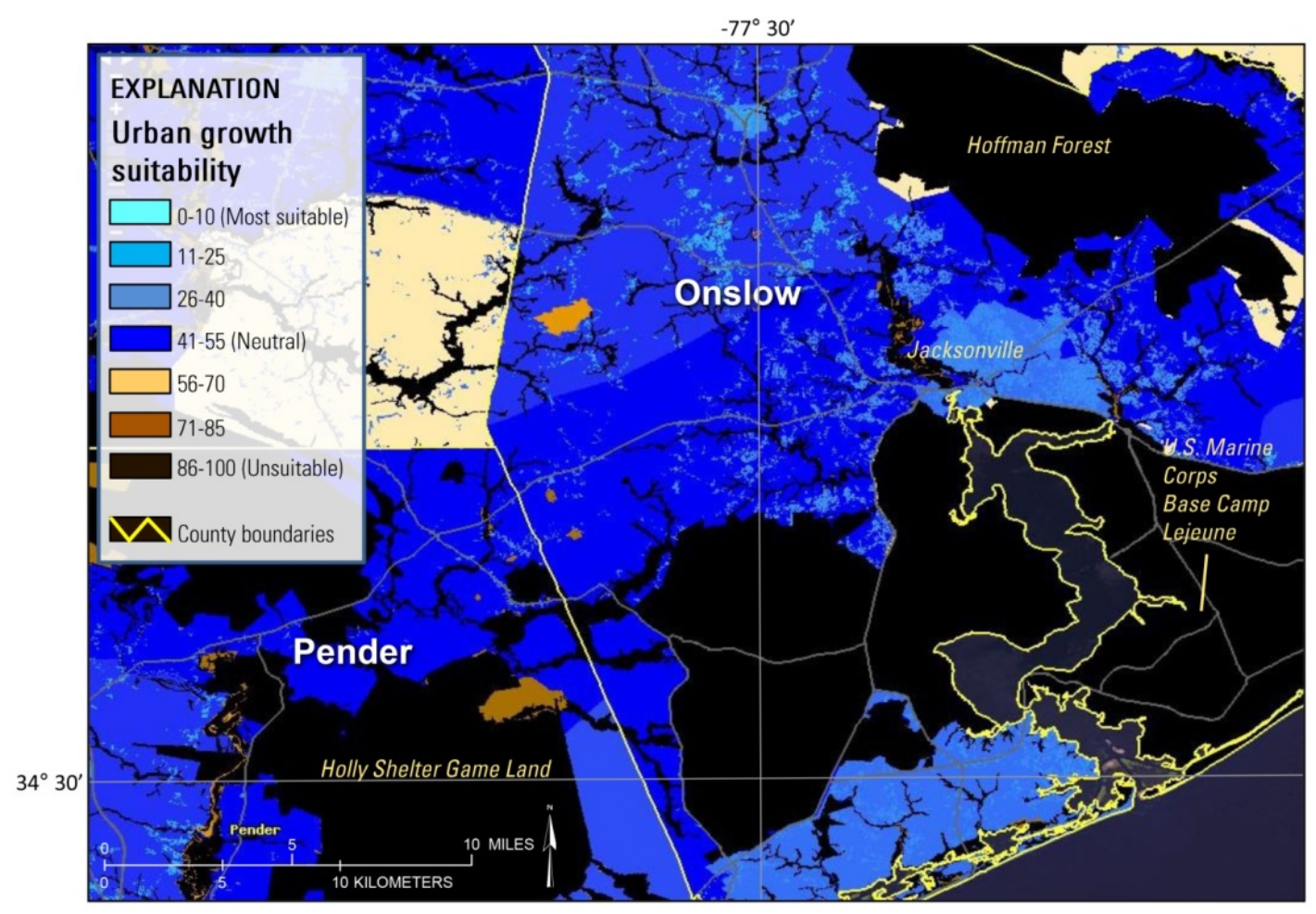

Figure 9. Relative suitability for urban growth in Onslow County, North Carolina, and surrounding areas to the west. In this example, the Holly Shelter Game Land to the west of U.S. Marine Corps Base Camp Lejeune, Camp Lejeune proper, and Hoffman Forest to the north are classified as unsuitable for growth (black), while the town of Jacksonville is classified as highly suitable (light shades of blue). 


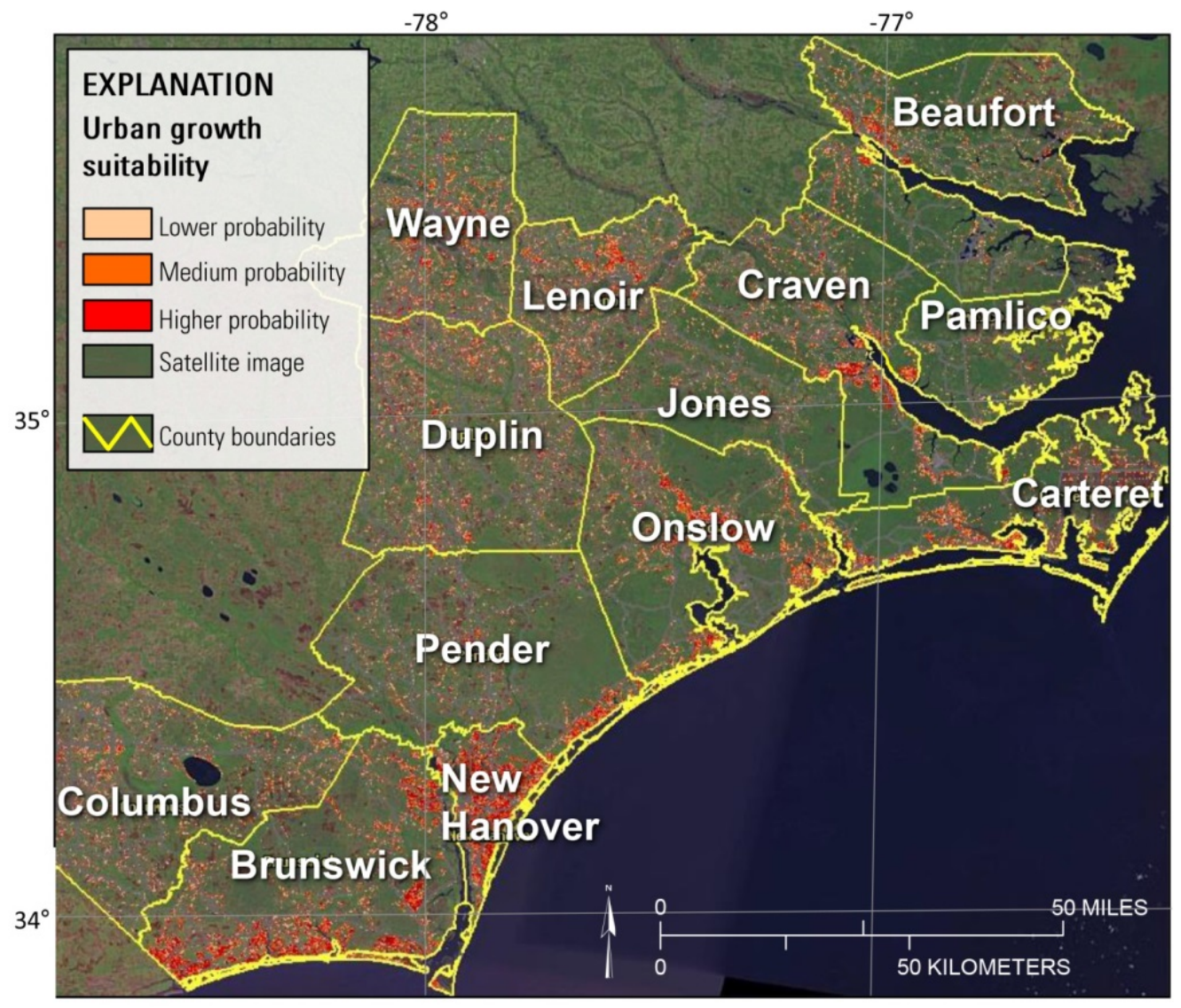

Figure 10. Probability of urban growth in southeastern North Carolina by the year 2030. Lighter shades of pink indicate lower probabilities of growth, while shades of orange and red indicate higher probabilities. This map indicates the areas in which urbanization is more or less likely. It does not indicate the density of urbanization. Pixel size is 250 meters. 


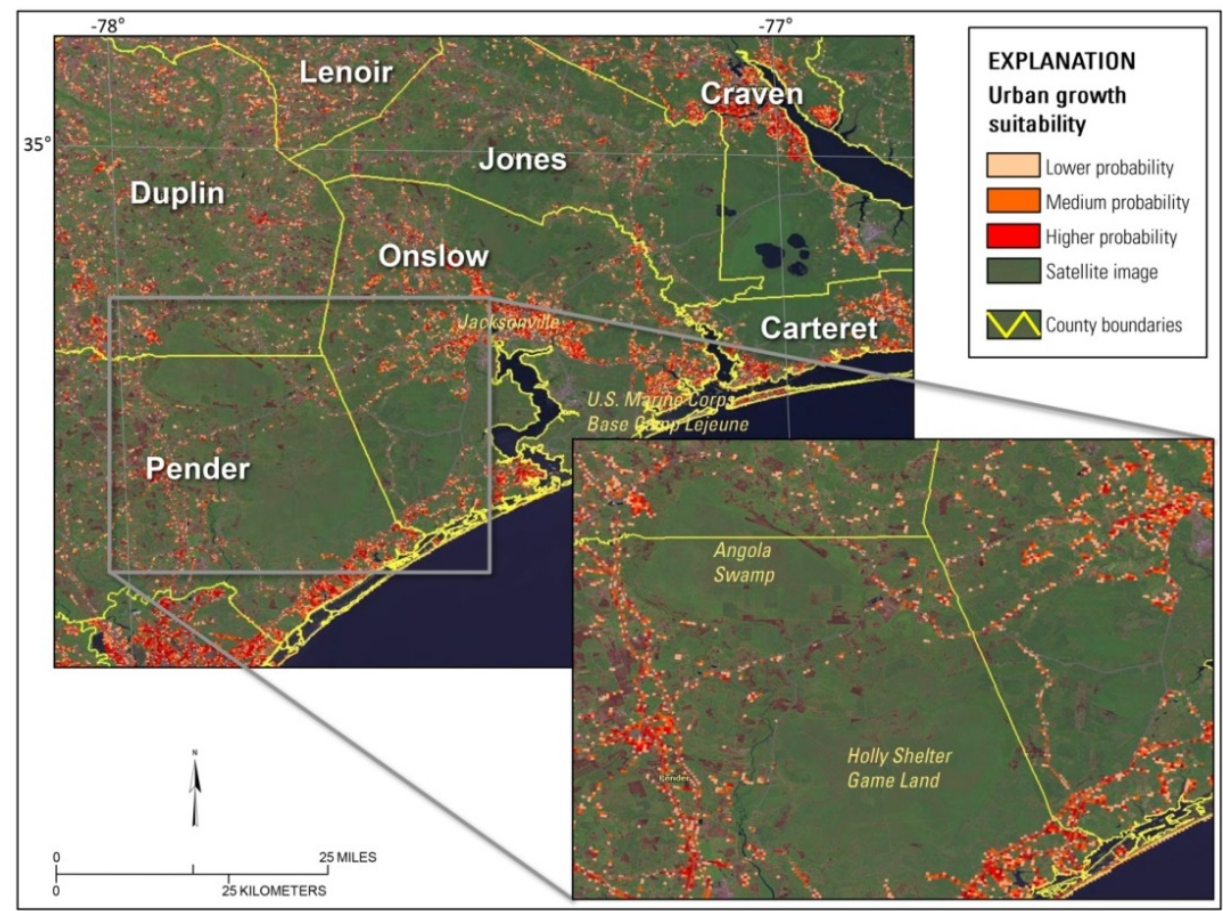

Figure 11. Probabilities of urban growth in Onslow County, North Carolina, and surrounding areas by the year 2030. Note the absence of predicted growth within the Holly Shelter Game Land, Angola Swamp, and U.S. Marine Corps Base Camp Lejeune; the growth predicted around the perimeters of these areas; and growth predicted in the town of Jacksonville. Pixel size is 250 meters.

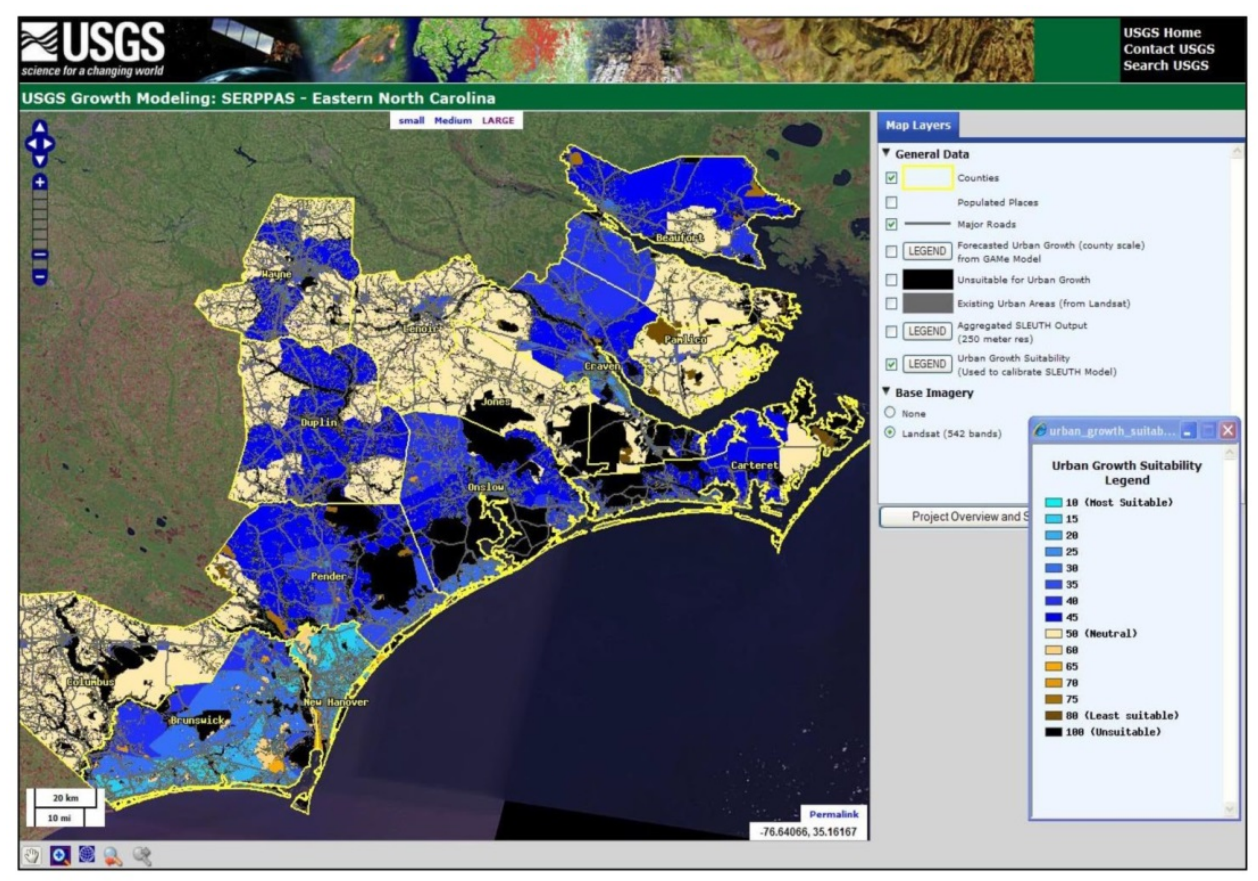

Figure 12. Web-based map viewer image showing growth suitability layer. 


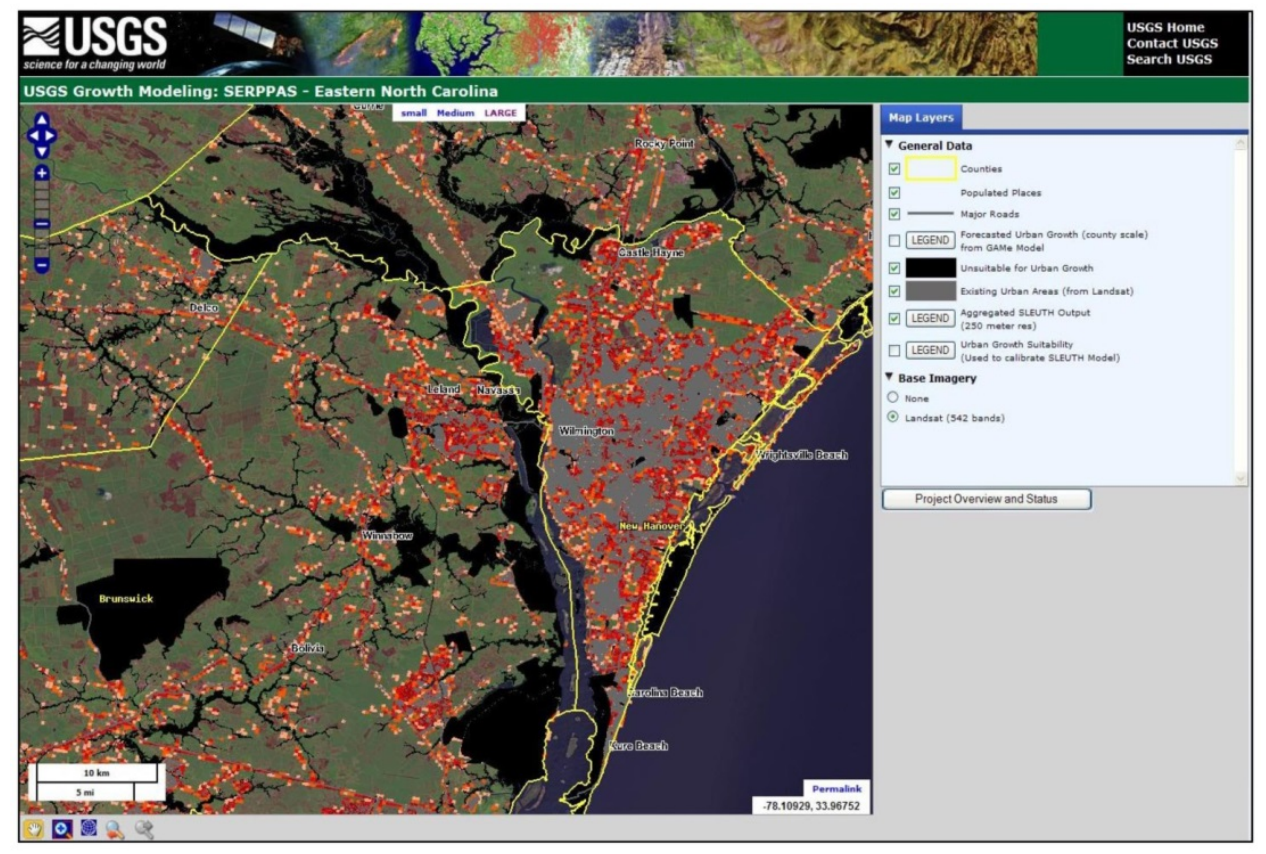

Figure 13. Web-based map viewer image showing detail of urban growth forecasts for Wilmington, North Carolina, and surrounding areas. 
$A$
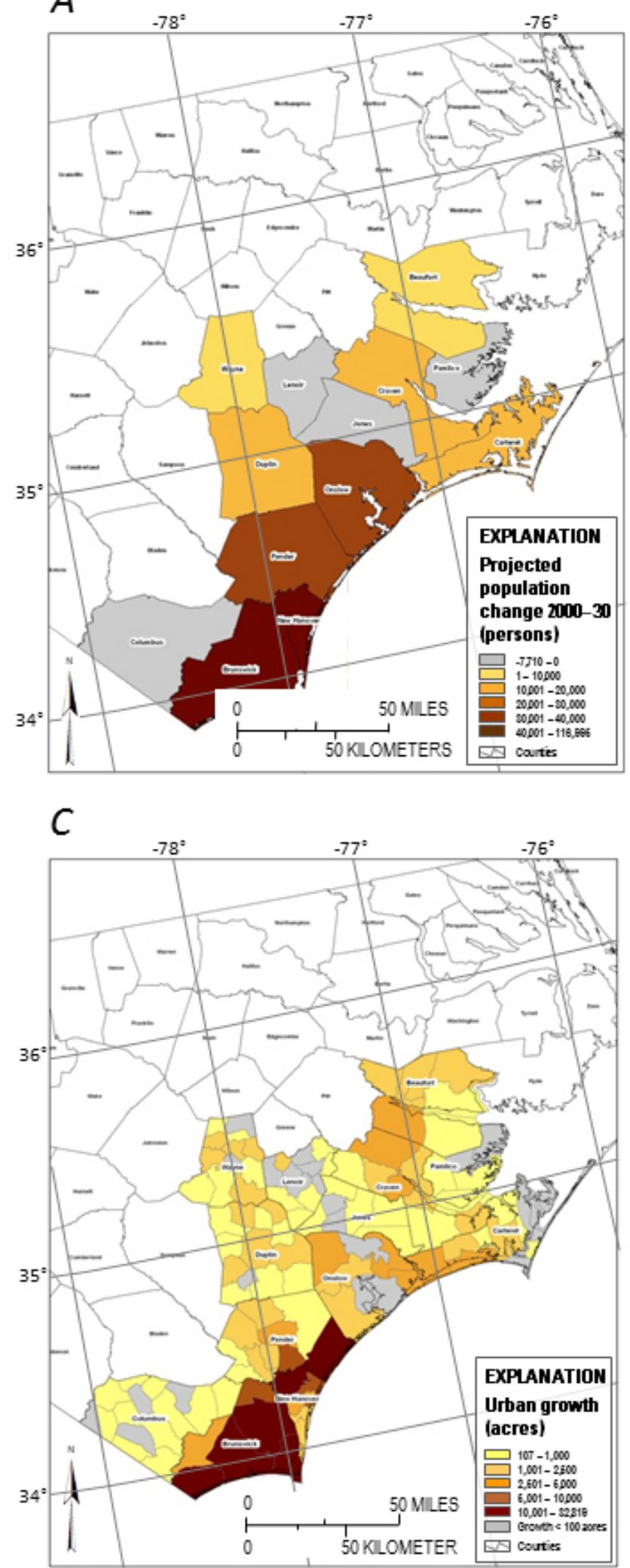

$B$
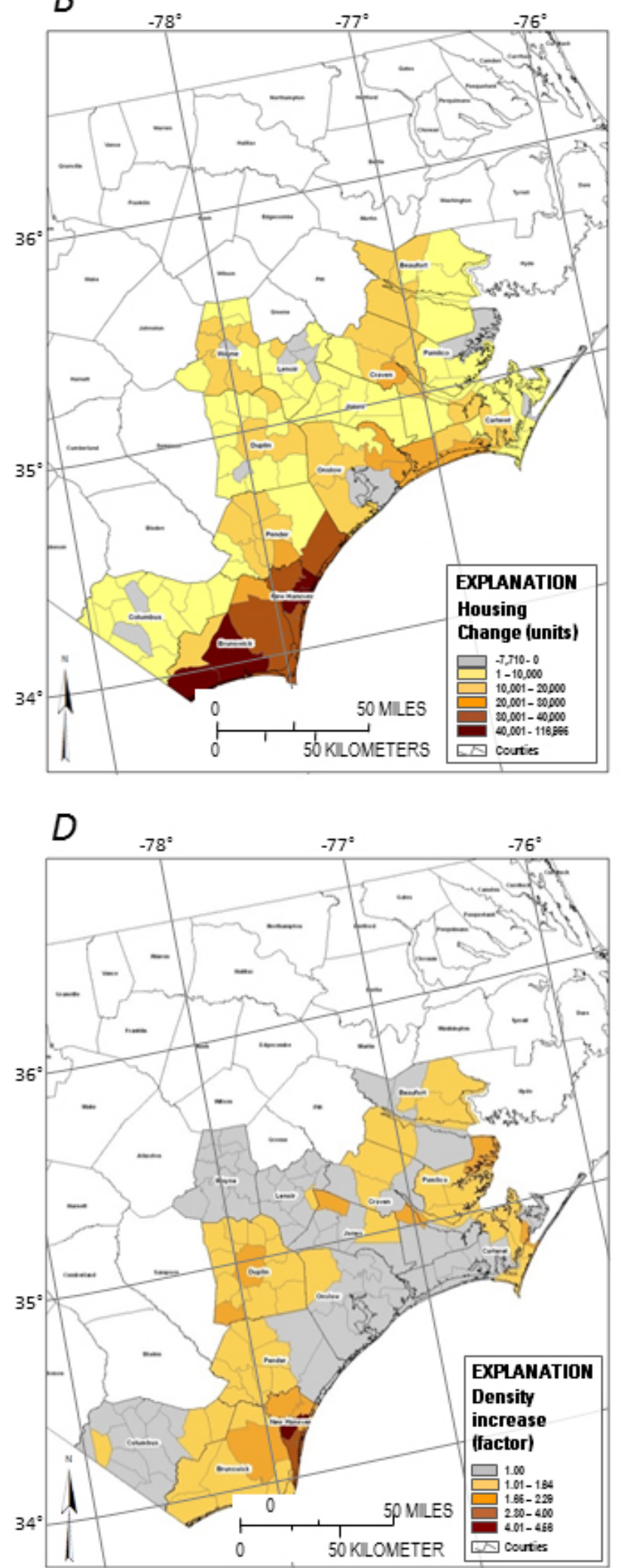

Figure 14. Results from the GAMe model for 2000-30. A, Projected county population growth. B, County population projections converted to future housing demand by township. $C$, Estimated urban land demand by township. $D$, Forecasted decrease in residential lot size. 

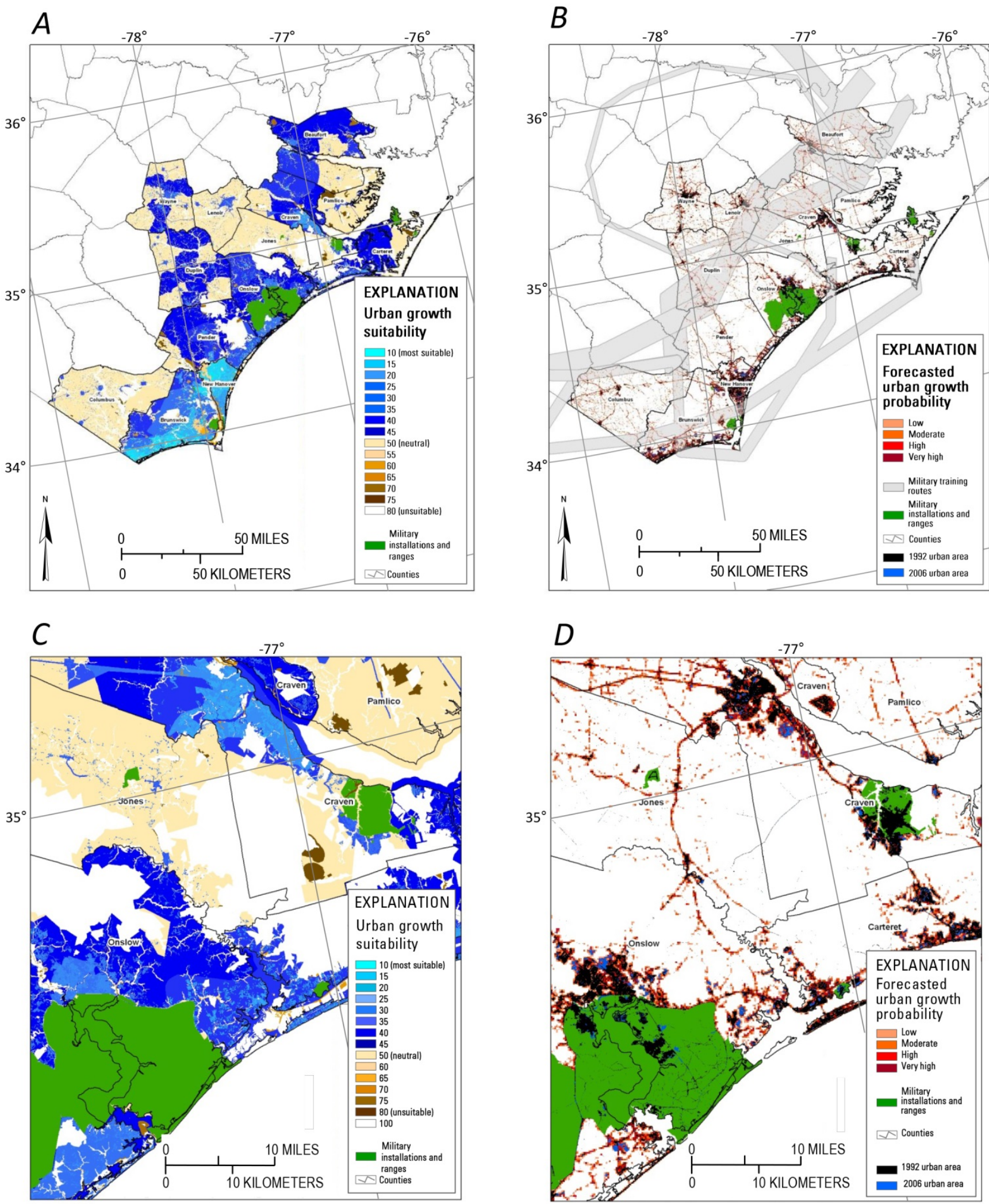

Figure 15. Results from the SLEUTH model. $A$, Suitability of land for urban development. $B$, Forecasted urban growth and military-use areas for 1992-2006. C, Suitability of land in Onslow and Craven Counties, North Carolina. $D$, Forecasted urban growth in Onslow and Craven Counties for 1992-2006. 

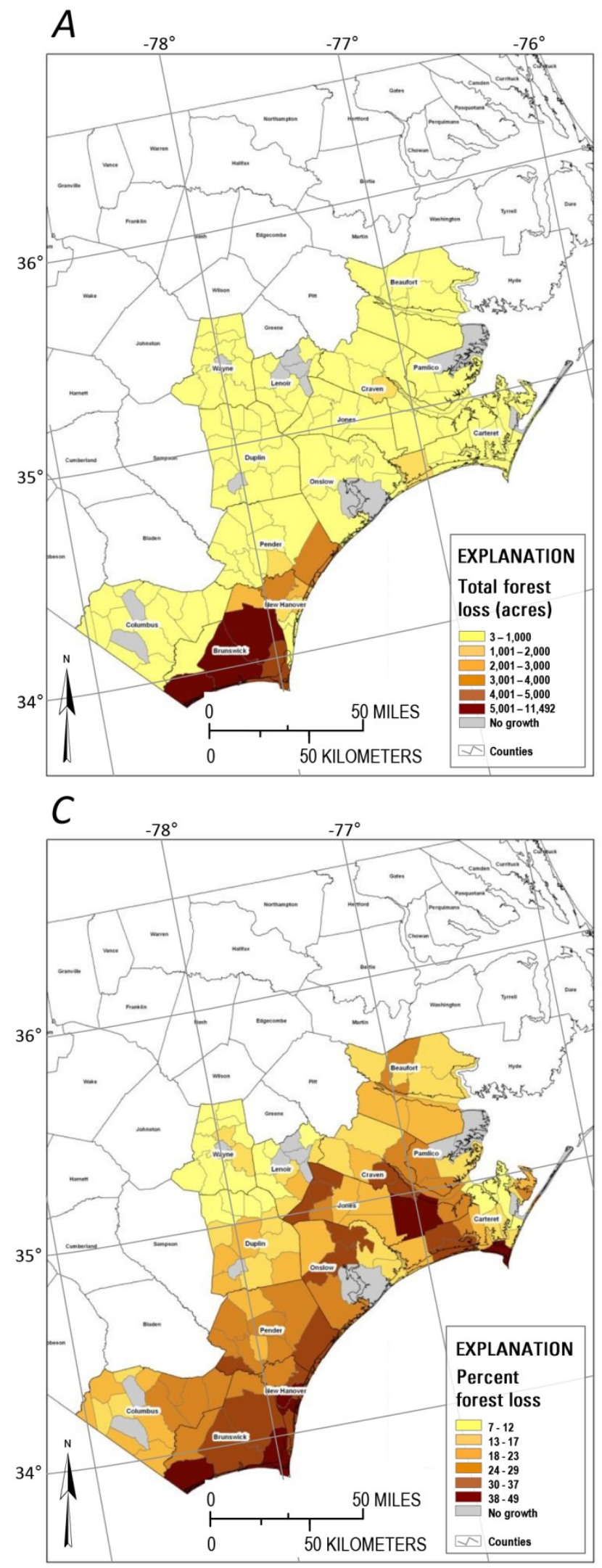
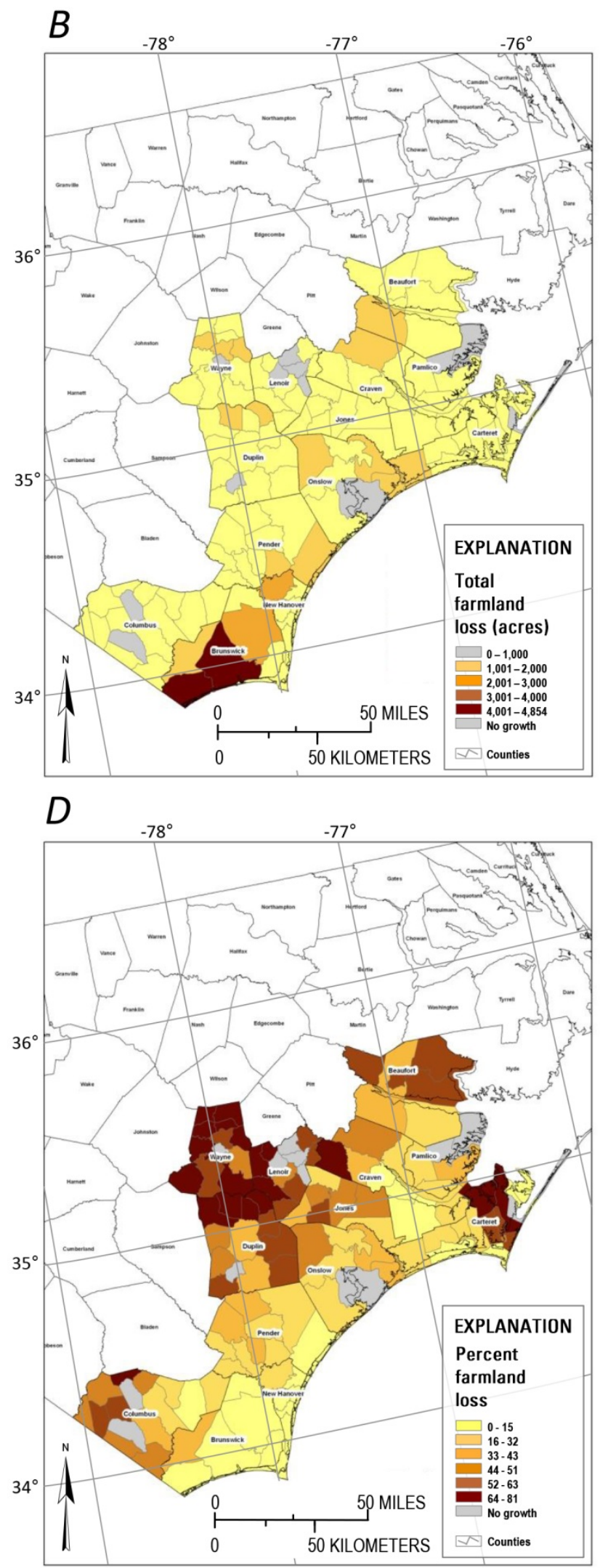

Figure 16. Results from the combination of the GAMe and SLEUTH models. A, Total forest loss forecast for the region by township. $B$, Total farmland loss forecast by township. $C$, Proportion of the total acreage converted to urban currently in forest. $D$, Proportion of the total acreage converted to urban currently in farmland. 
ISSN 2331-1258 (online)

http://dx.doi.org/10.3133/ofr20141125 